\title{
Photovoltaic Self-Consumption in Industrial Cooling and Refrigeration
}

\author{
Antonio Javier Martínez-Calahorro ${ }^{1}$, Gabino Jiménez-Castillo ${ }^{1,2}$ (D), Catalina Rus-Casas ${ }^{1,3, *(D)}$, \\ Pedro Gómez-Vidal ${ }^{2,3}$ and Francisco José Muñoz-Rodríguez ${ }^{1,3}$ [D
}

1 Department of Electronic and Automatic Engineering, University of Jaén, Campus Lagunillas, 23071 Jaén, Spain; jmartinez@marweningenieria.com (A.J.M.-C.); gjimenez@ujaen.es (G.J.-C.); fjmunoz@ujaen.es (F.J.M.-R.)

2 Department of Electrical Engineering, University of Jaen, Campus Lagunillas, 23071 Jaén, Spain; pvidal@ujaen.es

3 Center for Advanced Studies in Earth Sciences, Energy and Environment, University of Jaén, 23071 Jaén, Spain

* Correspondence: crus@ujaen.es

Received: 11 November 2020; Accepted: 18 December 2020; Published: 21 December 2020

\begin{abstract}
The industrial sector has a great opportunity to reduce its energy costs through distributed generation. In this sense, the potential of photovoltaic self-consumption systems in the industrial cooling and refrigeration sector is shown. Two industries with photovoltaic self-consumption installations are shown and the electricity consumption profile of this type of industry which has a remarkable basal electricity consumption during daytime is analyzed. The matching between consumption and photovoltaic generation profiles is provided through the self-consumption and self-sufficiency curves considering different reporting periods (monthly and annual). Moreover, a new index is presented: self-sufficiency index for sunshine hours, $\varphi_{\mathrm{SS}, \mathrm{SH}}$. This index evaluates the performance of the photovoltaic self-consumption system when facing the consumption only during sunshine hours. This index may complement the self-sufficiency index and may improve the analysis of this type of systems in the industrial sector. Self-consumption indices of $90 \%$ may be provided. Moreover, self-sufficiency indices for total $(24 \mathrm{~h}$ ) and for sunshine hours of $25 \%$ and $50 \%$, respectively, for industry A, and $26 \%$ and $45 \%$ for industry B have been obtained. During daytime, half the load consumption in this type of industry may be covered by photovoltaics while achieving high levels of use of the photovoltaic energy generated.
\end{abstract}

Keywords: photovoltaic self-consumption; distributed generation; industrial cold; energy efficiency; energy relocation

\section{Introduction}

Renewable energies have gradually increased their contribution to global primary energy consumption; in 2018 they accounted for $10.8 \%$ of the total, according to the Association of Renewable Energy Companies (APPA). Likewise, renewable energies are still the fourth largest source of primary energy consumption in the world, after oil, coal, and natural gas. In the last place is nuclear energy, with a $4.4 \%$ representation of primary energy consumption. It is important to note that more than $84 \%$ of the primary energy consumed in the world still comes from fossil fuels. In Europe, renewable energies account for $15.5 \%$ of total primary energy consumption, $13.9 \%$ in Spain, a percentage very similar to Europe. This fact confirms the great dependence that still exists on fossil energy sources, more than $70 \%$, and the opportunity to apply renewable energies to solve the great energy dependence of many countries [1]. In this sense, it is important to note that the industrial sector represented $68 \%$ 
of the total electricity demand worldwide in 2019. The trend of this demand may be affected by the current crisis caused by the SARS-CoV-2 virus. At a global level, electricity demand during the first quarter of 2020 was $2.6 \%$ lower than during the first quarter of 2019, but it should be noted that generation based on renewable energy increased by 3\% [2]. According to the type of renewable energy, the most numerous installations are those of photovoltaic solar generation, which is causing a change in the electricity generation model [3].

Among the advantages that can be found in energy generation systems that use renewable resources, such as photovoltaic solar energy, is that they emit much less pollution than any other fossil fuel to produce electricity. This is in line with meeting the objectives of the Spanish and European Union energy policy. In addition, energy imports and payments for $\mathrm{CO}_{2}$ emissions are reduced, economic profitability and energy efficiency are increased, and transmission losses in the electricity networks are reduced $[4,5]$. In this sense, distributed generation, by means of photovoltaics, can represent an energy alternative where there is a relevant consumption of energy during daytime [6]. There are different applications, depending on technical, economic and environmental aspects, as well as user needs and the technology used [7]. The concept of distributed generation is not yet internationally agreed upon, as each country has different legislation regarding renewable energies and their connection to the electricity system $[8,9]$. In Spain, it is defined as the set of electricity generation systems that are connected within the distribution networks [10]. These systems are characterized by their relative small power and their location close to the points of consumption [11].

The potential for distributed generation such as photovoltaic self-consumption depends on the matching between the consumption and generation profiles. In the literature, there are several studies that analyze the suitability of photovoltaic (PV) self-consumption in the residential sector [12-15]. However, considering photovoltaic self-consumption in the industrial sector, very few references can be found in the literature that address the impact of photovoltaic solar energy on electricity consumption and energy efficiency. In this sense, an analysis of different opportunities for energy efficiency in food industry is provided in [16]. A control method based on energy optimization for a cane sugar plant, which analyses different energy sources, including photovoltaics, is given in [17]. Moreover, in Reference [18] photovoltaic systems on Algerian dairy farms are analyzed and it is shown that the reliability of the electricity grid is improved in periods of maximum load, while reducing greenhouse gas emission. In Reference [19] it is highlighted the continuous interruptions in the electricity supply suffered by the industry in Pakistan. In order to overcome this handicap and using HOMER software, a hybrid network with different renewable energies has been designed, including photovoltaics, for the industrial sector. There may be found other examples of how photovoltaic solar energy can be technically feasible in the industrial sector and could solve numerous problems, as in the Philippines [20]. Uganda has developed a study in the industrial sector, with 36 industries, focused on the inclination and the surface of photovoltaic solar plants [21]. In Reference [22] it is analyzed the viability of integrated photovoltaic systems in industrial buildings in Greece while [23] shows that the investment in photovoltaics in the industrial sector of ferroalloys in Brazil has good appeal from the financial market point of view. Moreover, it has been shown that incorporating photovoltaic systems for energy supply can make the production of this industry suffer no interruption. As is the case of the food industry, i.e., eatables items like biscuits or breads; industries placed in areas where the continuous supply of electrical energy is a major problem [24]. There may be also found different studies in wineries that provide a techno-economic analysis based on HOMER software, where the operation of the factory is driven by the renewable energy generated by a photovoltaic array during the production process [25], or the feasibility study of photovoltaic systems connected to the grid for different types of oil mills in Andalusia (southern Spain) [26]. Regarding olive mills, the effect of inclination and orientation angles of the photovoltaic array over the self-consumption and self-sufficiency indices in photovoltaic self-consumption systems without energy storage is also analyzed [27]. Moreover, the feasibility of this renewable energy source in this type of industry is shown. 
It should be highlighted that there are industries that present a consumption profile with high basal consumption and little variability during daylight hours, which makes them ideal candidate for photovoltaic self-consumption. The industrial refrigeration and cooling industries stand out, which also show a notable increase in consumption in summer that can be balanced with the increase in electricity generation by photovoltaic arrays in this same season.

The refrigeration sector in Spain, according to the Association of Cold Storage Companies and their Technologies, has experienced a growth of 7 to 15 percent in the last 3 years, registering a turnover of more than 5000 million euros in 2018 and adding 22,000 direct jobs with one hundred percent employability rates. This volume includes the different activities of the value chain, from the manufacture and distribution of components to the manufacture and sale of equipment, and the execution and maintenance of commercial refrigeration and industrial refrigeration installations. Behind these figures are more than 5000 certified installation companies, more than 200 manufacturers, consultants and marketers of refrigeration supplies and equipment whose work transcends the refrigeration sector. This is because refrigeration is necessary to carry out the productive processes of a large number of business sectors. Some of them are very relevant for the Spanish economy, such as the food industry and distribution and the hotel and catering industry. Together they account for around 40 percent of GDP and both are absolutely dependent on the proper functioning of the cold chain [28]. In these sectors, refrigeration is synonymous with food safety and quality assurance for millions of consumers. Another sector of activity in which refrigeration and the cold sector are essential and which also have a great social impact is the pharmaceutical sector: many medicines-including vaccines-require cold for their manufacture and preservation. It can be also mentioned other sectors such as telecommunications, the textile sector or the automotive industry as productive areas that use in an intensive way, Table 1. In this way, cooling is an important element of productivity. However, the commitment of the refrigeration industry to environmental sustainability has also made it an ally for companies in all the sectors we have mentioned to meet their sustainability objectives and to respond to the climate change-related demands of their customers.

As stated before, additional research may be necessary in order to study the potential of photovoltaic self-consumption systems in the industrial sector. It should be noted that in this sector too many different consumption profiles can be found, depending on the productive processes that are carried out in the industries. Therefore, an ad hoc analysis is necessary to study the adequacy of the photovoltaic generation profile to the given consumption profile of each type of industry. The main objective of this manuscript is to highlight the role of this type of systems in Industrial Cooling and Refrigeration as the consumption profiles of this type of industry may be well matched with the generation profiles of photovoltaic systems. In this sense, the self-consumption and self-sufficiency curves, considering a certain range of the photovoltaic generator power, will be used to analyze the suitability of this type of distributed generation in this type of industry. Likewise, a new index will be provided: self-sufficiency index for sunshine hours, which will improve the analysis of self-consumption photovoltaic systems installed in industries. Given that the consumption profiles of companies tend to be very varied, depending on the power consumption, the equipment required for their production processes and the production schedules, this index will make it possible to quantify the level of matching of the generation and consumption profiles exclusively in the hours when photovoltaic generation exists. This parameter can be of significant interest since it indicates the level of coverage of this technology, limiting itself exclusively to the consumption existing in the period of time in which this energy source is active. At the same time, it makes it possible to better characterize this type of installation in the industrial sector where the consumption profile is very varied and can be unequally distributed throughout the day, unlike in the residential sector. It should be highlighted that in the case of the latter, electricity consumption is generally very low between 0:00 and 6:00, which is not the case in the industrial sector. Furthermore, this new parameter together with economic ones may be also used to provide a new design approach to better size the array in this type of systems. 
Table 1. Industrial cold applications by type of industrial sector.

\begin{tabular}{|c|c|}
\hline Sector & Application \\
\hline Pharmaceutical and hospital & White and clean rooms \\
\hline Logistic & $\begin{array}{c}\text { Robotic cold stores } \\
\text { Picking areas } \\
\text { Antechambers } \\
\text { Self-supporting warehouses }\end{array}$ \\
\hline Fruit vegetable & $\begin{array}{c}\text { Cold rooms with controlled atmospheres } \\
\text { Rapid forced air cooling } \\
\text { Water cooling } \\
\text { High vacuum cooling }\end{array}$ \\
\hline Meat & $\begin{array}{c}\text { Channel cold rooms } \\
\text { Process rooms } \\
\text { Clean or white rooms } \\
\text { Dryers } \\
\text { Cold rooms for finished products } \\
\text { Freezing tunnels } \\
\text { Blast chillers } \\
\text { Freezing cold rooms } \\
\text { Heated packaging rooms }\end{array}$ \\
\hline Dairy & Cold rooms for dairy products \\
\hline Fishing & $\begin{array}{c}\text { Boat cooling } \\
\text { Refrigeration of reception areas and markets } \\
\text { Ice factories } \\
\text { Cold storage } \\
\text { Refrigeration of fish workers } \\
\text { Freezing }\end{array}$ \\
\hline Hospitality and restoration & $\begin{array}{l}\text { Cold rooms in large central kitchens } \\
\text { Small cold rooms for restaurants } \\
\text { Installation of blast chillers } \\
\text { Freezing tunnels }\end{array}$ \\
\hline Bakery and pastry & $\begin{array}{c}\text { Freezing tunnels, continuous static or spiral } \\
\text { Refrigerated bakery workers } \\
\text { Controlled fermentation chambers } \\
\text { Freezing chamber for precooked } \\
\text { Small pastry chambers }\end{array}$ \\
\hline $\begin{array}{l}\text { Distribution, hypermarkets } \\
\text { and supermarkets }\end{array}$ & $\begin{array}{c}\text { Separate cold rooms } \\
\text { Cold storage plants for vegetables, meat, fish, dairy } \\
\text { Freezer chambers } \\
\text { Butcher shop workers with a view towards the store } \\
\text { Bread workers } \\
\text { Refrigeration equipment by air or by water } \\
\text { Ice and flake generators }\end{array}$ \\
\hline
\end{tabular}

The article is structured as follows. The first section presents the industrial refrigeration industries that have been monitored in order to provide real data. The consumption profile of this type of industry is characterized and the methodology used to analyze the suitability of the photovoltaic systems for self-consumption in this type of industry through the self-consumption and self-sufficiency indices is presented. In addition, a new self-sufficiency index for sunshine hours is provided to characterize photovoltaic self-consumption systems in the industrial sector. Moreover, Zero point Energy Industry (ZEI) point is defined. The following section analyses the different self-consumption and self-sufficiency curves, during total and regarding sunshine hours, considering different reporting periods (monthly and annual). Finally, conclusions are drawn in the last section. 


\section{Materials and Methods}

\subsection{Consumer Profiles of Industrial Refrigeration and Cooling Companies}

Two industries of the industrial refrigeration sector in Spain have been monitored for one year. In both industries it has been installed photovoltaic self-consumption systems. In this sense, data regarding electricity consumption, photovoltaic generation and photovoltaic self-consumption have been collected. It has been considered a storage or recording interval of 5 min either for the power consumed and the photovoltaic power generated [29]. This recording time is appropriate as the consumption profile of this type of industry shows little variability.

The first industry analyzed in this article, Industry A, and whose main activity is cold storage, is located in the southern region of Spain. It has cold stores with a capacity of $35,000 \mathrm{~m}^{3}$ and a freezing temperature of $-24^{\circ} \mathrm{C}$. The annual electricity consumption corresponding to the year of measurement was 2,024,583.50 kWh, and the electricity generation of the photovoltaic self-consumption facility installed on its roof was $76,819.44 \mathrm{kWh}$. The electrical characteristics of the self-consumption photovoltaic system are shown in Figure 1a. Likewise, the accumulated daily values of energy consumption and photovoltaic generation are shown in Figure 2. Moreover, daily load and photovoltaic generation profiles are shown in Figure 3.

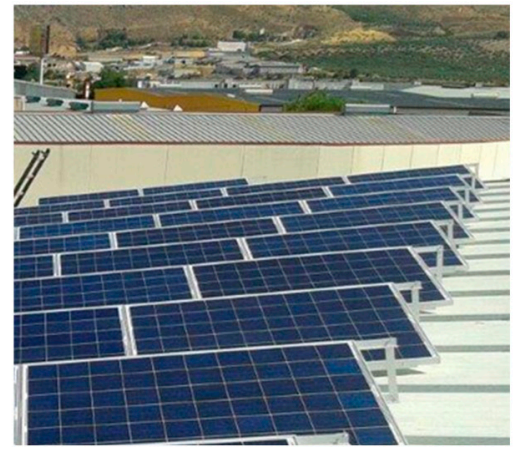

(a)

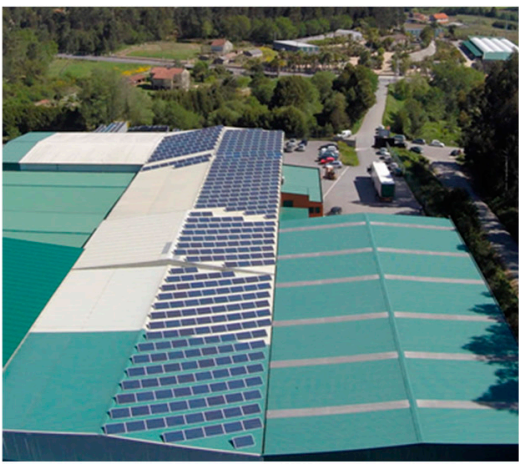

\section{Location}

Southern area of Spain

Andalusia

Characteristics

Peak power:

No. of panels:

Panel power:

Brand of panels:

No. Investors:

Invertor model:

Brand of investors:

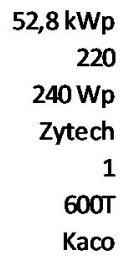

Location

Northern area of Spain

Galicia

$\begin{array}{lr}\text { Characteristics } & \\ \text { Peak power: } & 110,2 \mathrm{kWp} \\ \text { No. of panels: } & 16 / 22 / 387 \\ \text { Panel power: } & 255 / 250 / 260 \mathrm{Wp} \\ \text { Brand of panels: } & \text { Csun } \\ \text { No. Investors: } & 2 \\ \text { Invertor model: } & 600 \mathrm{TL} \\ \text { Brand of investors: } & \text { Kaco }\end{array}$

(b)

Figure 1. (a) Data of the photovoltaic self-consumption generation installation, industry A; (b) Data of the photovoltaic self-consumption generation installation, industry B.

Industry B also belongs to the industrial refrigeration sector but differs from the previous one in that it also has a productive process of separation, calibration and packaging of its product. However, its most representative consumption is due to storage in cold rooms, as is the case with industry A. It is located in the northern region of Spain. The electricity consumption in the annual period was $1,026,312.34 \mathrm{kWh}$, and the electricity generation of the photovoltaic self-consumption facility installed on their roof was $128,307.78 \mathrm{kWh}$. The electrical characteristics of the self-consumption photovoltaic system are shown in Figure 1b. Cumulative daily consumption and generation values and daily load 
and photovoltaic generation profiles are shown in Figures 2 and 4, respectively. It can be seen that self-consumption photovoltaic system corresponding to industry $B$ has twice the power that industry A. However, it does not provide twice the photovoltaic generation, as irradiation is a very important variable in this type of systems (industry A is located in the south of Spain while industry B is in the north).

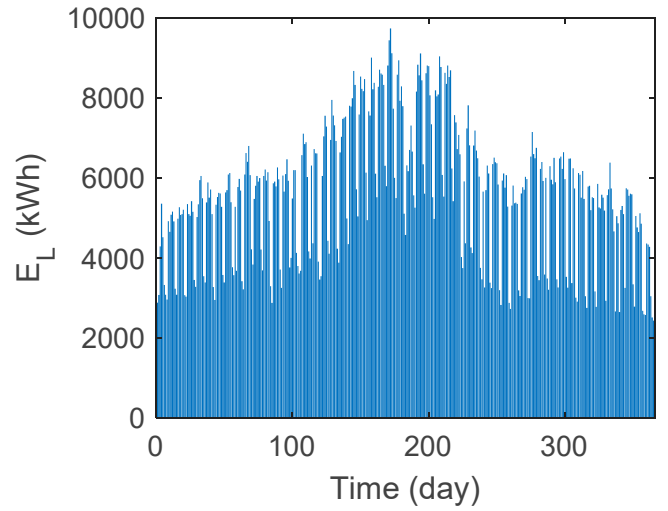

(a)

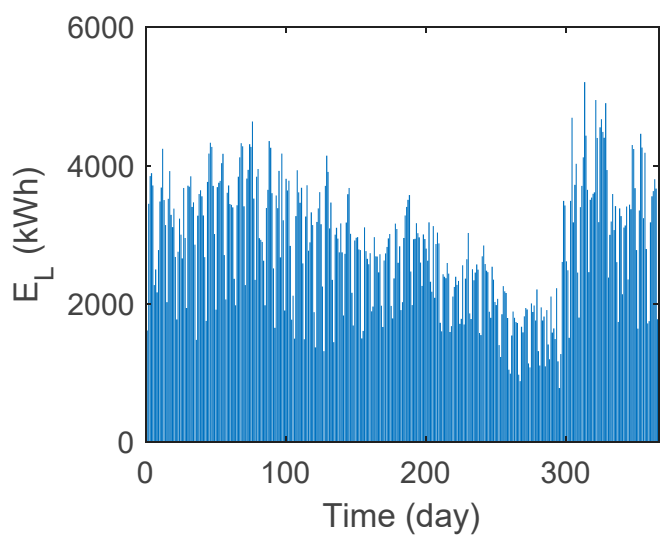

(c)

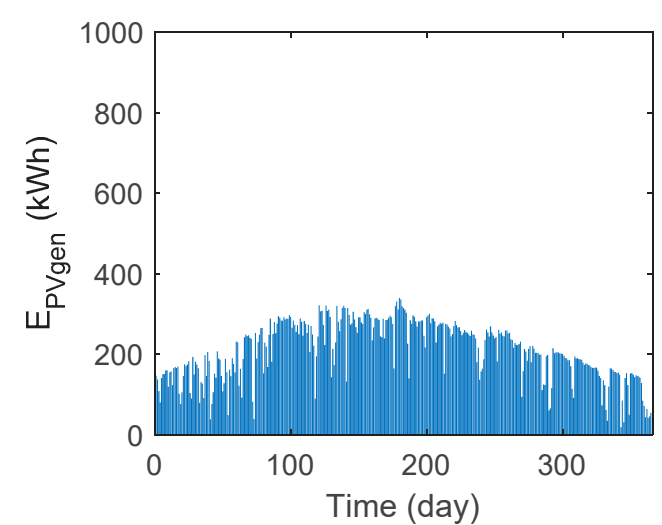

(b)

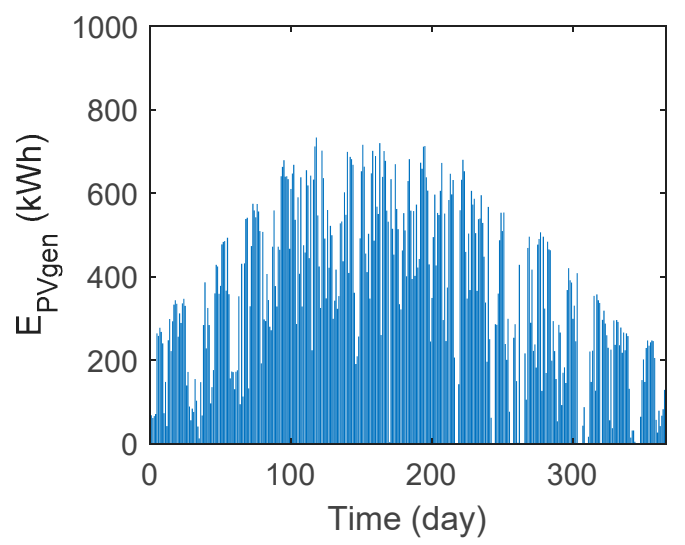

(d)

Figure 2. Bar graphs for cumulative daily consumption and photovoltaic generation ( $\mathrm{kWh} /$ day) corresponding to industry A and B throughout a year (365 bars). (a) Industry A-Daily consumption data; (b) Industry A-Daily generation data; (c) Industry B-Daily consumption data; (d) Industry B-Daily generation data.

As can be seen in Figure 2, industry A presents high daily energy consumption on the central days of the year, coinciding with summer, reaching $8000 \mathrm{kWh} /$ day on specific days of the season. On the other hand, the lowest consumption is obtained for winter days, decreasing consumption, in this case, to $4000 \mathrm{kWh} /$ day. On the other hand, industry B carries out other productive and complementary activities to those of the cold sector itself, especially in the winter season, which means that the annual consumption curve has a different shape. In this way, it can be seen that, for industry B, its daily consumption reaches $2500 \mathrm{kWh} /$ day in summer. With respect to photovoltaic generation in industry A, on summer days, when there is more solar radiation, generation can exceed $300 \mathrm{kWh} /$ day on specific summer days. On the other hand, it can be seen in the graphs of industry B, in terms of photovoltaic generation they are similar in shape to that of industry A, but with different magnitude as the array powers of the facilities are different and they are located at different latitudes. 


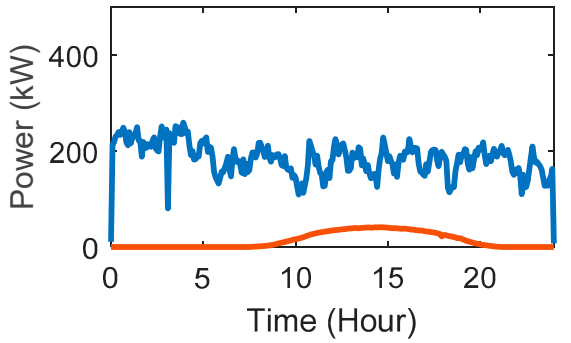

(a)

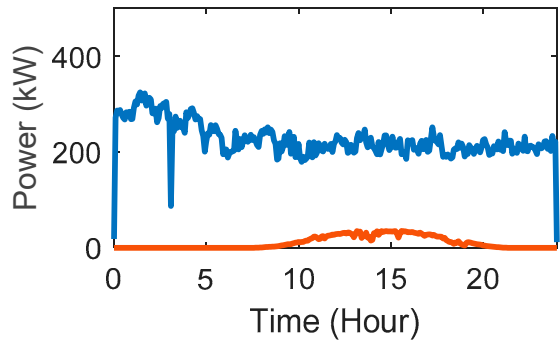

(c)

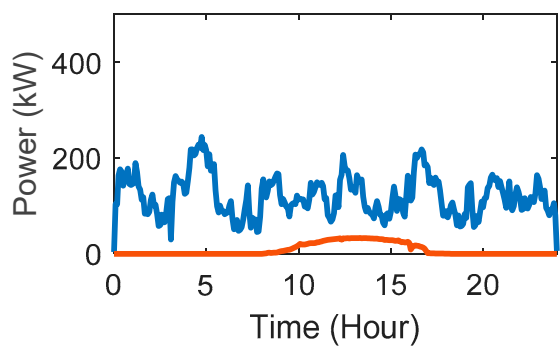

(e)

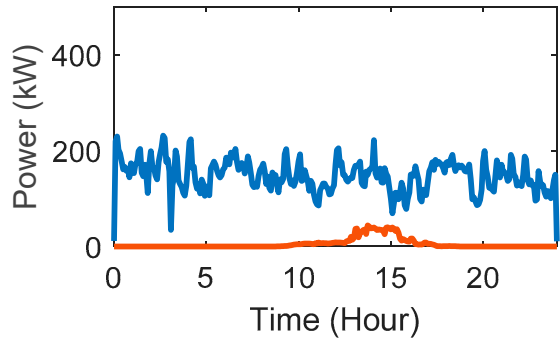

(g)

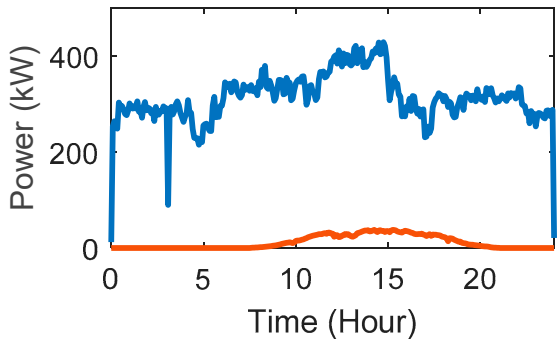

(b)

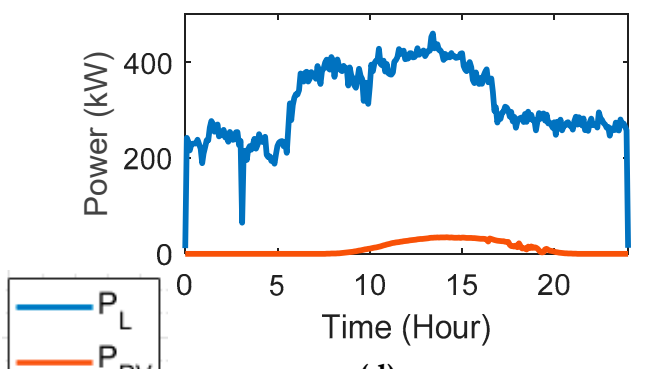

(d)

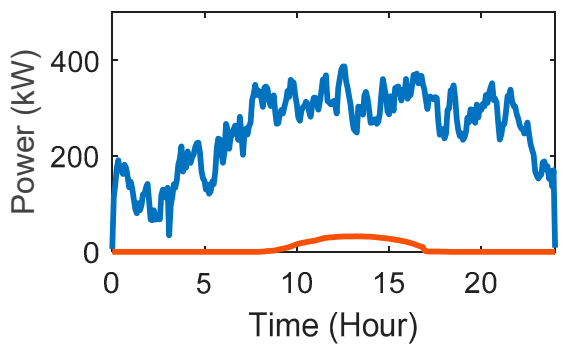

(f)

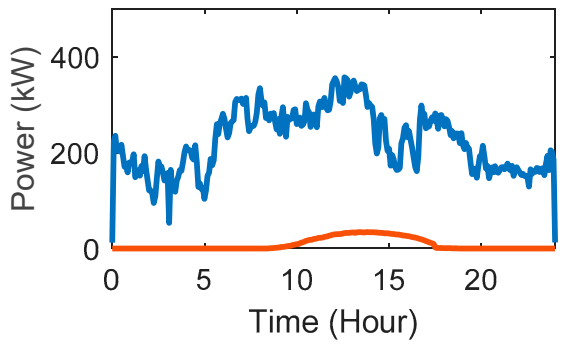

(h)

Figure 3. Daily load and photovoltaic generation profiles. Industry A. (a) Weekend-May 6; (b) Labor Day-May 4; (c) Weekend-August 6; (d) Labor Day-August 7; (e) Weekend-November 5; (f) Labor Day-November 6; (g) Weekend-February 4; (h) Labor Day-February 6.

With regard to the daily consumption profiles, it should be noted that the industrial refrigeration industry generally presents a very characteristic consumption profile that is repeated in the majority of companies in this sector, Figures 3 and 4 . They differ only in the magnitude of the power consumed, which depends on the size of the industry. In this sense, this type of industry has an electricity consumption with a relative high basal consumption with little fluctuations during the day which varies throughout the year depending on the ambient temperature, with the highest electricity consumption in spring and summer when this temperature is higher and the lowest electricity consumption in winter, when the ambient temperature is lower. Likewise, the consumption may be increased during sunshine hours due to other services and management activities that are carried out during daylight hours to keep the industry running. This characteristic of increased consumption during sunshine hours can facilitate the matching between the generation and consumption profiles in this type of industry. 


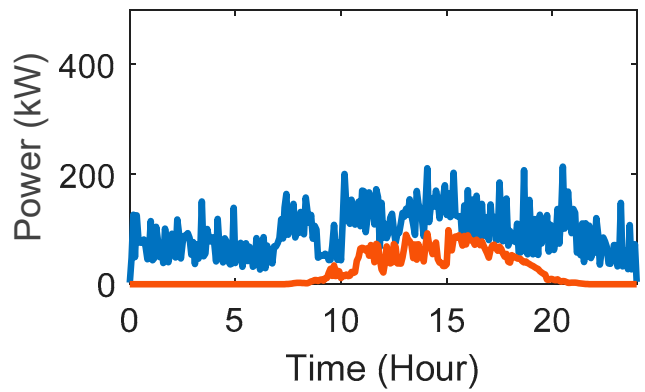

(a)

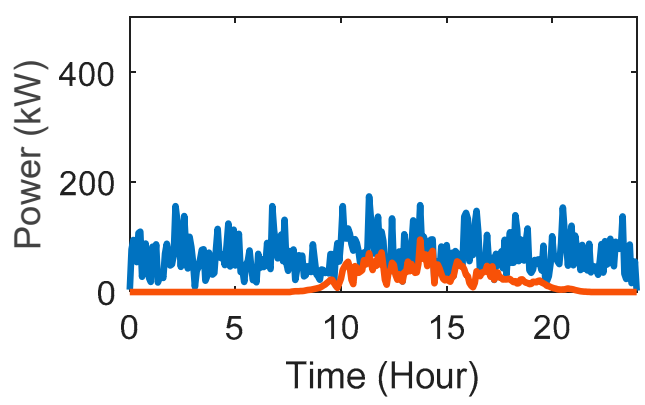

(c)

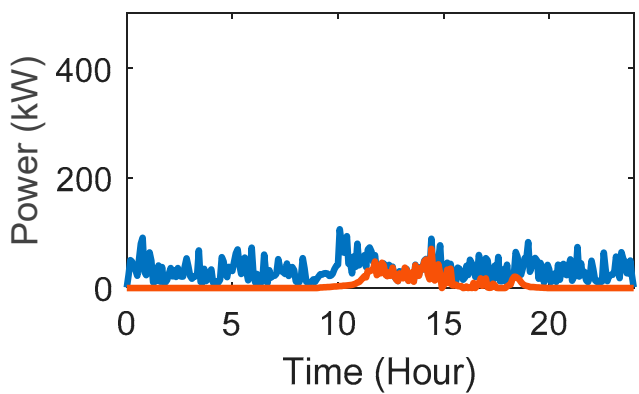

(e)

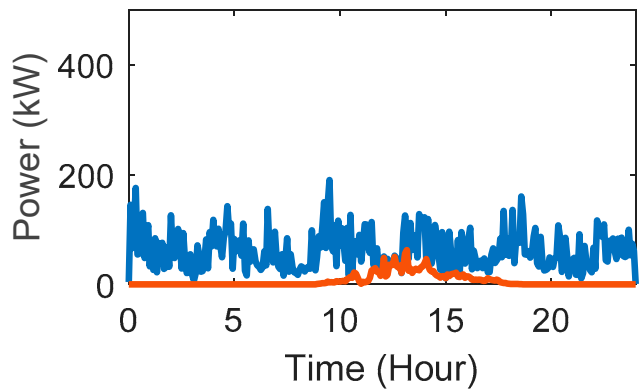

(g)

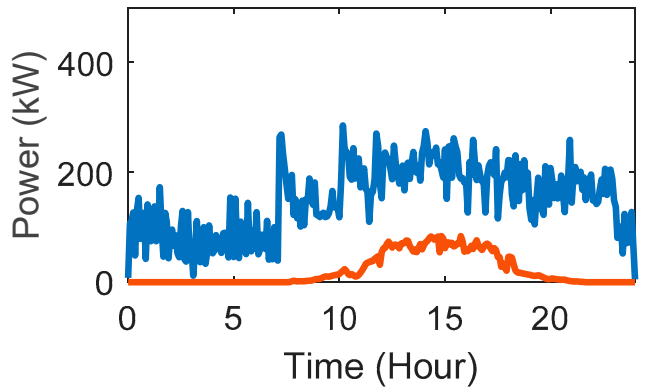

(b)

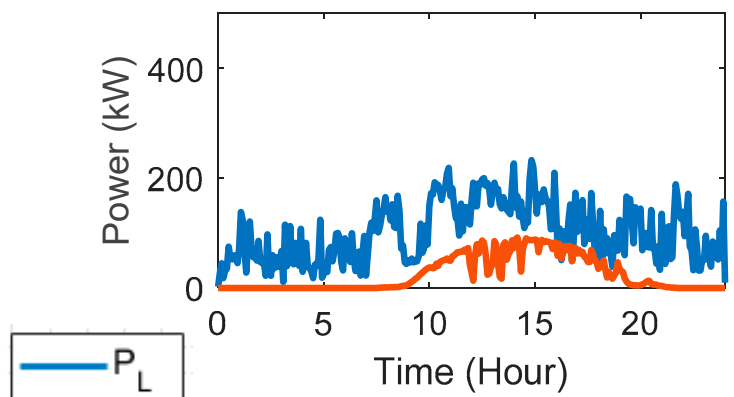

(d)

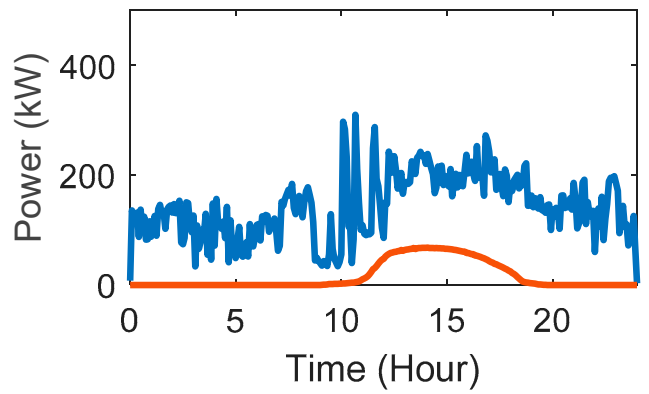

(f)

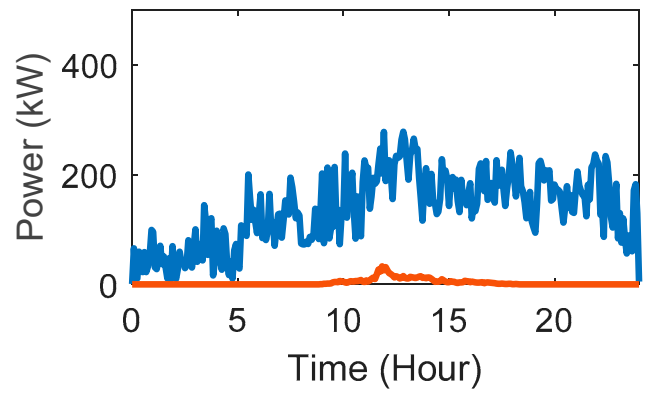

(h)

Figure 4. Load and photovoltaic generation profiles. Industry B.(a) Weekend-May 6; (b) Labor Day-May 4; (c) Weekend-July 30; (d) Labor Day-July 31; (e) Weekend-October 22; (f) Labor Day-October 26; (g) Weekend-February 5; (h) Labor Day-February 6.

Based on the daily power consumption and generation profiles, it can be seen that for industry A, Figure 3, both on non-working days and on working days, and in all seasons, there is a basal consumption, which is maintained $24 \mathrm{~h}$ a day and it is even higher during sunshine hours in labor days. As can be seen, it is greater in summer and spring months, where it may generally reach $300 \mathrm{~kW}$ in labor days, while in autumn and winter months this basal consumption may be around $250 \mathrm{~kW}$. For industry B, there is a basal consumption which is also greater during sunshine hours in labor days. In this case, this basal consumption may reach, at least, $100 \mathrm{~kW}$. 


\subsection{Generation Profiles}

In Figures 3 and 4, the generation profiles together with the consumption profiles of each industry are shown, both for holidays and for labor days. It can be also seen that the photovoltaic generation profiles of the facilities installed in industry A and B correspond, respectively, to clear skies and to skies which often present a greater variability throughout the year. This is due to their location: industry A and B are located in southern and northern Spain, respectively. In these graphs, it is possible to appreciate the coupling that occurs in the daytime between both curves, generation and consumption, obtaining a good matching. As can be seen in Figures 3 and 4, the energy production with photovoltaic from both industries is practically self-consumed. Likewise, the good coupling between photovoltaic generation and consumption in industry $B$ is also remarkable, even better than that observed for industry $\mathrm{A}$ as load consumption profile is considerably above photovoltaic generation profile. However, if the aim is to supply the greatest amount of photovoltaic energy to be self-consumed, it may be possible to increase the power of the photovoltaic installation corresponding to industry A in order to increase the energy of photovoltaic generation without wasting it.

In order to analyze the suitability of photovoltaic self-consumption systems it may be plotted self-sufficiency and self-consumption curves for a given array peak power range. Moreover, the output power of a photovoltaic self-consumption system considering a determined recording interval can be calculated as:

$$
\mathrm{P}_{\mathrm{Pv}, \tau_{\mathrm{k}}}^{\mathrm{k}}=\xi_{\mathrm{pv}, \tau_{\mathrm{k}}}^{\mathrm{k}} \times \mathrm{P}_{0}(\mathrm{~kW})
$$

where $\mathrm{P}_{\mathrm{Pv}_{\mathrm{v}}}^{k}$ is the photovoltaic power for the photovoltaic self-consumption system for each k period, $\tau_{\mathrm{k}}$ is the recording period, $\mathrm{P}_{0}(\mathrm{~kW})$ is the rated power, $\xi_{\mathrm{pv}}^{k}(\mathrm{p} . \mathrm{u})$ is the per-unit PV power output at each $\mathrm{k}$ period which is irradiance function, ambient temperature and photovoltaic system efficiency [30]. These simplifies expressions have been used in other similar studies [31,32]. In this way, a range of $P_{0}$ from $0.01 \mathrm{kWp}$ to $2 \mathrm{MWp}$ was used with a step of $10 \mathrm{kWp}$. The upper limit has been chosen in order to properly plot the aforementioned curves.

As mentioned above, both PV power profiles has been measured for one year. The cold storage industries $\mathrm{A}$ and $\mathrm{B}$ have a PV array of $52.8 \mathrm{kWp}$ and $110.2 \mathrm{kWp}$ and with a final yield $\left(\mathrm{Y}_{\mathrm{f}}\right)$ of $1455 \mathrm{kWh} / \mathrm{kW}_{\mathrm{p}}$ and $1164 \mathrm{kWh} / \mathrm{kW}_{\mathrm{p}}$, respectively. $\mathrm{Y}_{\mathrm{f}}$ defined by IEC 61,724 is calculated as the AC net energy output of the PV system ( $\left.\mathrm{E}_{\text {out }}\right)$ per rated $\mathrm{kW}(\mathrm{DC})$ of installed PV array $\left(\mathrm{P}_{0}\right)$ [33]:

$$
\mathrm{Y}_{\mathrm{f}}=\frac{E_{\text {out }}}{\mathrm{P}_{0}}\left(\frac{\mathrm{kWh}}{\mathrm{kWp}}\right)
$$

Once the electrical consumption and generation profiles of the industries have been characterized, the self-consumption and self-sufficiency indices are used to determine the behavior of the photovoltaic self-consumption installations with respect to consumption demanded by the industry.

\subsection{Self-Sufficiency and Self-Consumption Indices. Self-Sufficiency Index for Sunshine Hours Index $\varphi_{S S, S H}$}

The self-consumption index $\left(\varphi_{\mathrm{sc}}\right)$ can be defined as the ratio of self-consumed photovoltaic energy $\left(\mathrm{E}_{\mathrm{PV}, \mathrm{con}}\right)$ and generated photovoltaic energy $\left(\mathrm{E}_{\mathrm{PV}, \text { gen }}\right)$, Equation (3), and indicates the level of use of self-consumed photovoltaic energy with respect to the generated photovoltaic energy. On the other hand, the self-sufficiency index $\left(\varphi_{\mathrm{ss}}\right)$ provides the percentage of the energy consumption $\left(\mathrm{E}_{\mathrm{L}}\right)$ that is covered from the generated photovoltaic energy, Equation (4) [34,35]. Figure 5 shows an example of a daily photovoltaic consumption and generation profiles, where the different areas used for the calculation of self-consumption and self-sufficiency indices can be observed.

$$
\varphi_{\mathrm{sc}, \tau}=\frac{\mathrm{E}_{\mathrm{PV}, \mathrm{con}, \tau}}{\mathrm{E}_{\mathrm{PV}, \mathrm{gen}, \tau}}
$$




$$
\varphi_{\mathrm{ss}, \tau}=\frac{\mathrm{E}_{\mathrm{PV}, \mathrm{con}, \tau}}{\mathrm{E}_{\mathrm{L}, \tau}}
$$

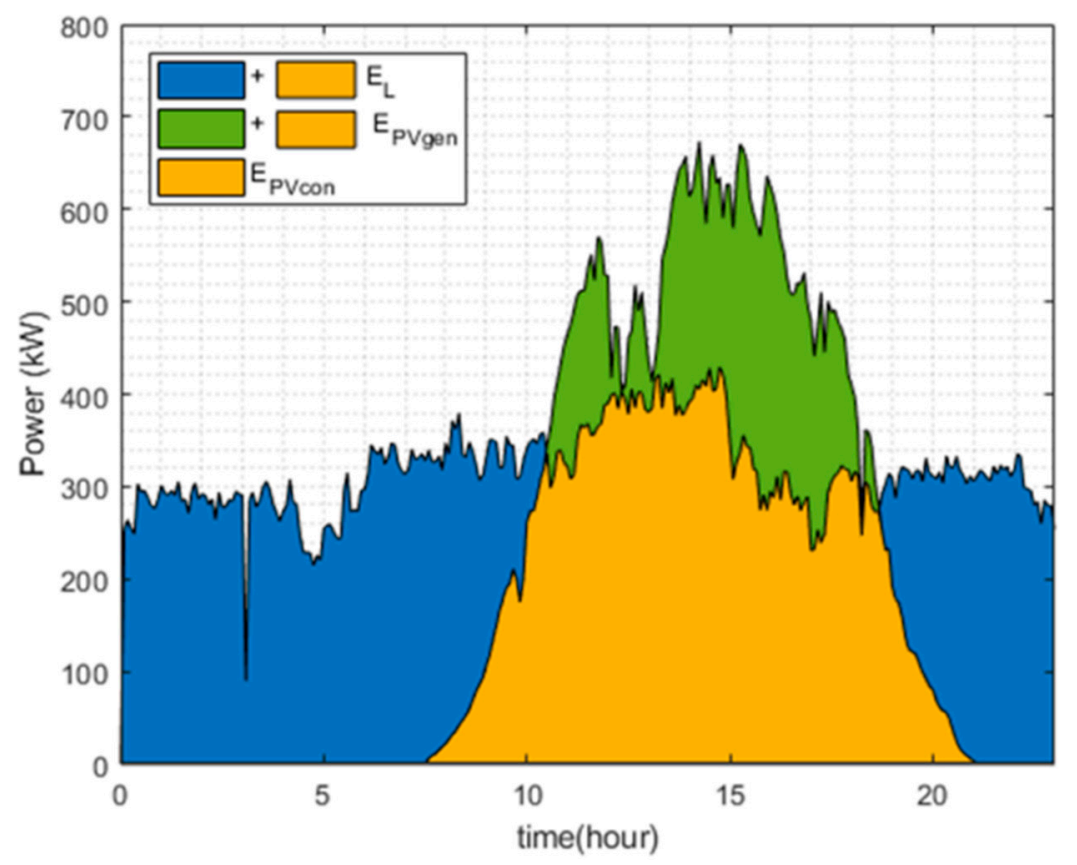

Figure 5. Daily load and photovoltaic generation profiles. Load consumption (blue + orange areas), $\mathrm{E}_{\mathrm{L}}$, photovoltaic generation (orange + green areas), $\mathrm{E}_{\mathrm{PV}, \text { gen }}$, and photovoltaic self-consumed energy (orange area), $\mathrm{E}_{\mathrm{PV}, \mathrm{con}}$.

$\tau$ corresponds to the reporting period (daily, monthly or annual). In this sense, daily, monthly and annual self-consumption and self-sufficiency curves will be obtained and analyzed, both in total hours $(24 \mathrm{~h})$ and in sunshine hours for a given array power range. These two indices are generally used to characterize self-consumption photovoltaic systems. The self-sufficiency index considers the total energy consumed during all the daytime, whether there is photovoltaic generation or not. It should be noted that in the case of photovoltaic generators they only generate during a fraction of the day (from sunrise to sunset). In the case of self-consumption photovoltaic systems aimed at the residential sector, the generation period generally corresponds to the activity period of the homes, except for a few hours' delay before the tenants go to bed, so consumption decreases considerably at night (i.e., between 00:00 and 6:00 the consumption may be marginal). However, in the industrial sector each company may have a different consumption profile, which may or not depend on the photovoltaic generation period. In that sense, it may be interesting to define a new parameter that quantifies and evaluates the performance of the photovoltaic self-consumption system only during sunshine hours and evaluate the role that PV generators can play in coping with consumption in that period of time. This new parameter defined as self-sufficiency index for sunshine hours, $\varphi_{\mathrm{ss}, \mathrm{SH}}$, may be interesting to evaluate the level of coupling between the consumption and generation profiles for the aforementioned generation time. It can be also interesting when different complementary energy sources to the electricity grid are considered (e.g., wind and photovoltaic energy. $\varphi_{\mathrm{ss}, \mathrm{SH}}$ can be estimated as:

$$
\varphi_{\mathrm{ss}, \mathrm{SH}, \tau}=\frac{\mathrm{E}_{\mathrm{PV}, \mathrm{con}, \tau}}{\mathrm{E}_{\mathrm{L}, \mathrm{SH}, \tau}}
$$

where $\mathrm{E}_{\mathrm{L}, \mathrm{SH}, \tau}$ is the energy consumed during sunshine hours (from sunrise to sunset) for a given reporting period. Sunshine and night hours can be estimated by means of an astronomical model that determines when sunrise and sunset occur [36]. Table 2 provides the value of $\varphi_{\mathrm{sc}}, \varphi_{\mathrm{ss}}$ and $\varphi_{\mathrm{ss}, \mathrm{SH}}$ indices for each industry. 
Table 2. Final PV system yield, annual self-consumption index, annual self-sufficiency index and annual self-sufficiency index during sunshine hours.

\begin{tabular}{ccc}
\hline Parameter & Industry A & Industry B \\
\hline $\mathrm{Y}_{\mathrm{f}}(\mathrm{kWh} / \mathrm{kW})$ & 1455 & 1164 \\
$\varphi_{\mathrm{sc}}$ & 0.9999 & 0.9995 \\
$\varphi_{\mathrm{sS}}$ & 0.0375 & 0.1249 \\
$\varphi_{\mathrm{SS}, \mathrm{SH}}$ & 0.0726 & 0.2361 \\
\hline
\end{tabular}

Therefore, a photovoltaic self-consumption system can be better evaluated considering self-consumption and self-sufficiency indices together with the new proposed index. In order to get the self-sufficiency index for sunshine hours it is necessary to estimate the photovoltaic energy generated, $\mathrm{E}_{\mathrm{PV}, \text { gen }}$, Equation (6), the energy consumed by the installation $\mathrm{E}_{\mathrm{L}}$, Equation (7) and the energy consumed during sunshine hours, $\mathrm{E}_{\mathrm{L}, \mathrm{SH}}$, Equations (8) and (9), as well as the photovoltaic self-consumed energy, EPV,con, Equations (10) and (11).

$$
\begin{gathered}
\mathrm{E}_{\mathrm{PV}, \text { gen }, \tau}=\sum_{\mathrm{k}} P_{\mathrm{PV}, \text { gen }, \tau_{\mathrm{k}}}^{k} \times \tau_{\mathrm{k}} \\
\mathrm{E}_{\mathrm{L}, \tau}=\sum_{\mathrm{k}} P_{\mathrm{L}, \tau_{\mathrm{k}}}^{k} \times \tau_{\mathrm{k}} \\
P_{\mathrm{L}, \mathrm{SH}, \tau_{\mathrm{k}}}^{\mathrm{k}}= \begin{cases}\mathrm{P}_{\mathrm{L}, \tau_{\mathrm{k}}}^{\mathrm{k}} & \text { from sunrise to sunset } \\
0 & \text { from sunset to sunrise }\end{cases} \\
\mathrm{E}_{\mathrm{L}, \mathrm{SH}, \tau}=\sum_{\mathrm{k}} P_{\mathrm{L}, \mathrm{SH}, \tau_{\mathrm{k}}}^{\mathrm{k}} \times \tau_{\mathrm{k}} \\
\mathrm{P}_{\mathrm{PV}, \text { con, } \tau_{\mathrm{k}}}^{\mathrm{k}}= \begin{cases}\mathrm{P}_{\mathrm{L}, \tau_{\mathrm{k}}}^{\mathrm{k}} & \text { if } \mathrm{P}_{\mathrm{PV}, \text { gen }, \tau_{\mathrm{k}}}^{\mathrm{k}} \geq \mathrm{P}_{\mathrm{L}, \tau_{\mathrm{k}}}^{\mathrm{k}} \\
\mathrm{P}_{\mathrm{PV}, \text { gen }, \tau_{\mathrm{k}}}^{\mathrm{k}} & \text { if } \mathrm{P}_{\mathrm{PV}, \text { gen }, \tau_{\mathrm{k}}}^{\mathrm{k}}<\mathrm{P}_{\mathrm{L}, \tau_{\mathrm{k}}}^{\mathrm{k}}\end{cases}
\end{gathered}
$$

where $\tau_{k}$ corresponds to the recording interval and $\mathrm{k}$ is the number of recording intervals in the reporting period [33]. $\mathrm{P}_{\mathrm{PV} \text {,gen }}$ and $\mathrm{P}_{\mathrm{L}}$ corresponds to the output power and to the load power, respectively, of the photovoltaic system for each k period; $\mathrm{P}_{\mathrm{L}, \mathrm{SH}}$ is the load power during sunshine hours (from sunrise to sunset) for each $\mathrm{k}$ period and $\mathrm{P}_{\mathrm{PV}, \mathrm{con}}$ is the photovoltaic self-consumed power for each $\mathrm{k}$ period. Once $\mathrm{E}_{\mathrm{PV}, \mathrm{con}}$ is obtained, self-consumption and self-sufficiency indices can be estimated [32,34], Figure 6. In addition, self-sufficiency for sunshine hours, $\varphi_{\mathrm{SS}, \mathrm{SH}}$, has been included.

Regarding residential self-consumption, this range was considered to be between 0 and $10 \mathrm{~kW}$ since this interval represents the majority of power contracts in this sector [37]. In order to properly observe the shape of the curves mentioned above, the range has been extended to $2 \mathrm{MW}$. This study will make it possible to determine not only what percentage of the consumption can be covered with different array powers, it will be shown the potential of photovoltaic self-consumption for this type of industry characterized by a considerable basal consumption. To obtain the curves mentioned above, the method indicated in Figure 6 will be used for different $\tau$ : daily, monthly and annual. This will be done for each company and differentiating the analysis by total hours and sunshine hours. 


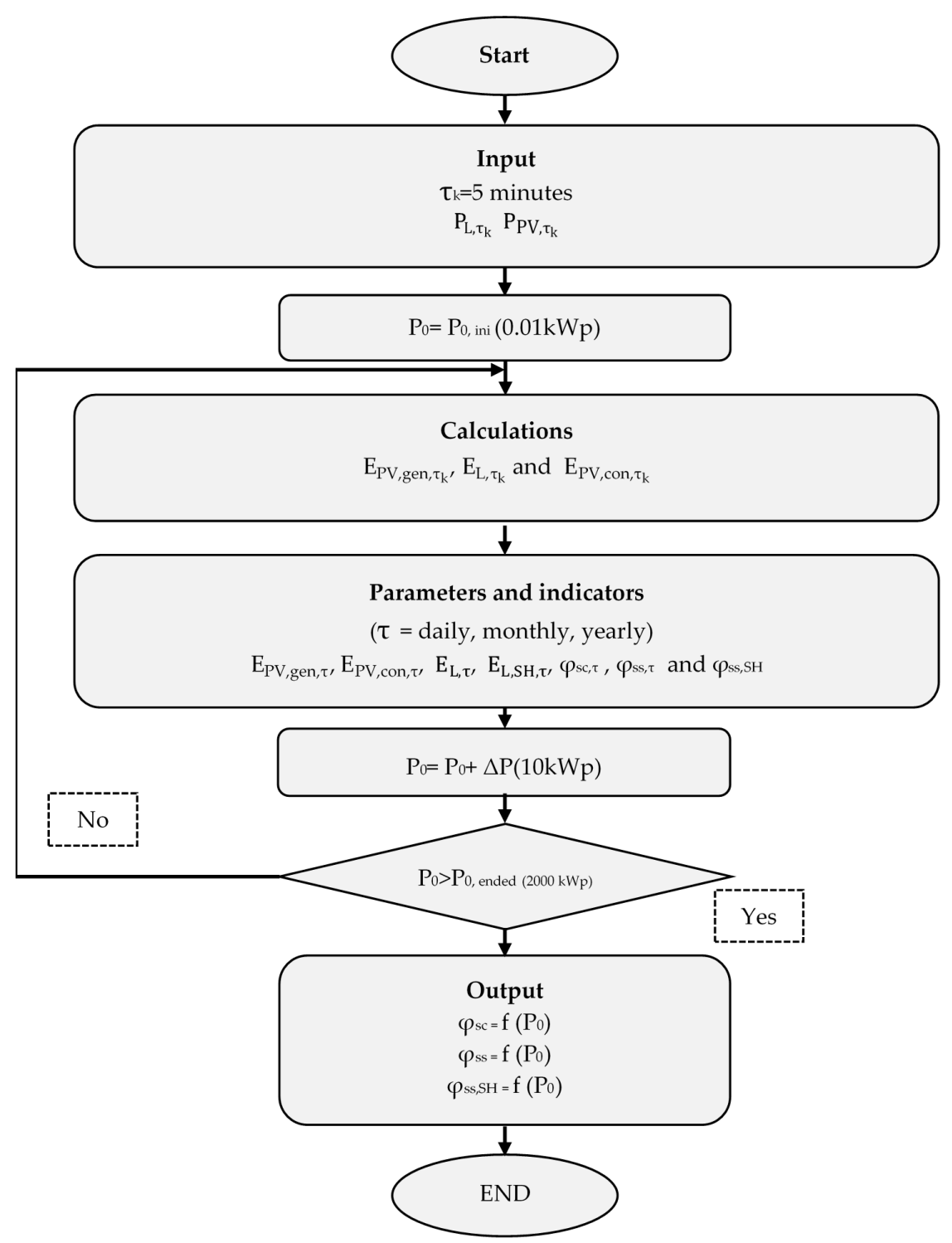

Figure 6. Method followed to estimate $\varphi_{\mathrm{SC}}, \varphi_{\mathrm{SS}}$ and $\varphi_{\mathrm{SS}, \mathrm{SH}}$, as a function of the nominal power of the array, $\mathrm{P}_{0}$.

\section{Results and Discussion}

With regard to industry A, Figure 7a shows the self-sufficiency and self-consumption curves for each month of the year. It can be seen how the self-consumption index present a value of $100 \%$ for a certain range of power. Thus, for July, the total use of the energy generated is achieved for array powers lower than $370 \mathrm{~kW}$. On the other hand, January only provides a 100\% self-consumption index up to $110 \mathrm{~kW}$. In relation to the monthly self-sufficiency curves, it should be noted that these show a linear behavior for a certain array power range. Outside this interval, the growth is no longer linear, becoming asymptotic. For July, a self-sufficiency index of $52 \%$ is reached for a power of the array of $2 \mathrm{MW}$, while if this same power is considered in the month of January this index is slightly higher than $30 \%$. Moreover, if the analysis is focused on the region of lineal behavior, for an array power of $400 \mathrm{kWp}$ a self-sufficiency index of $28 \%$ and $17 \%$ may be reached for July and January, respectively. 


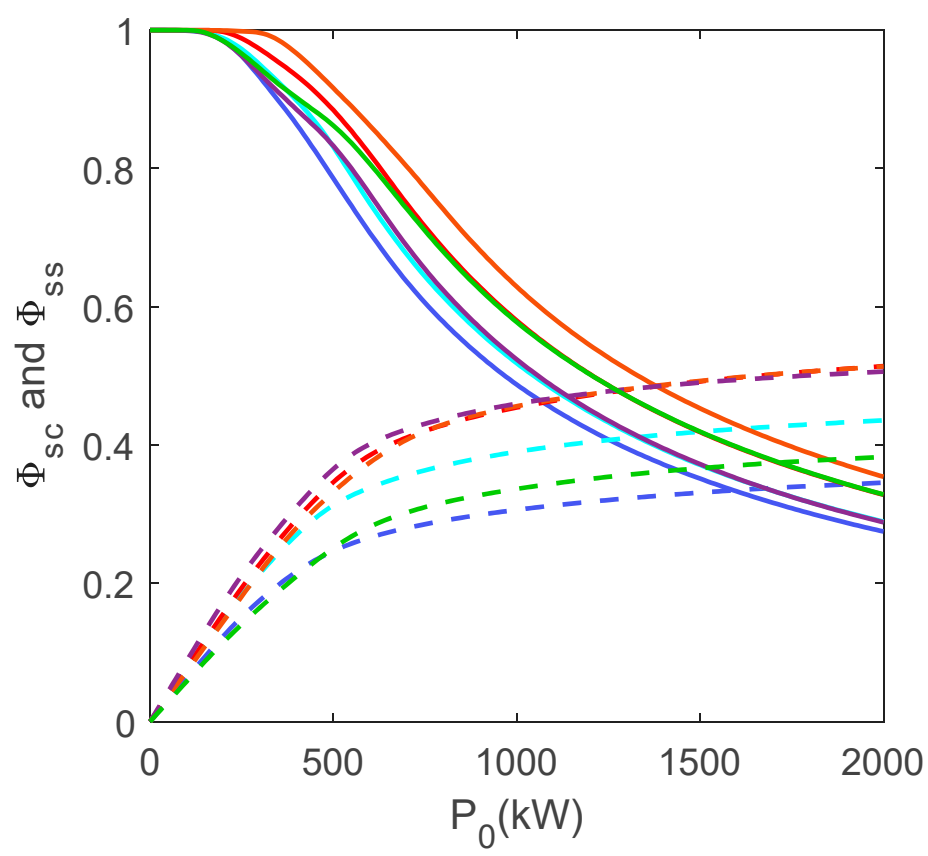

(a)

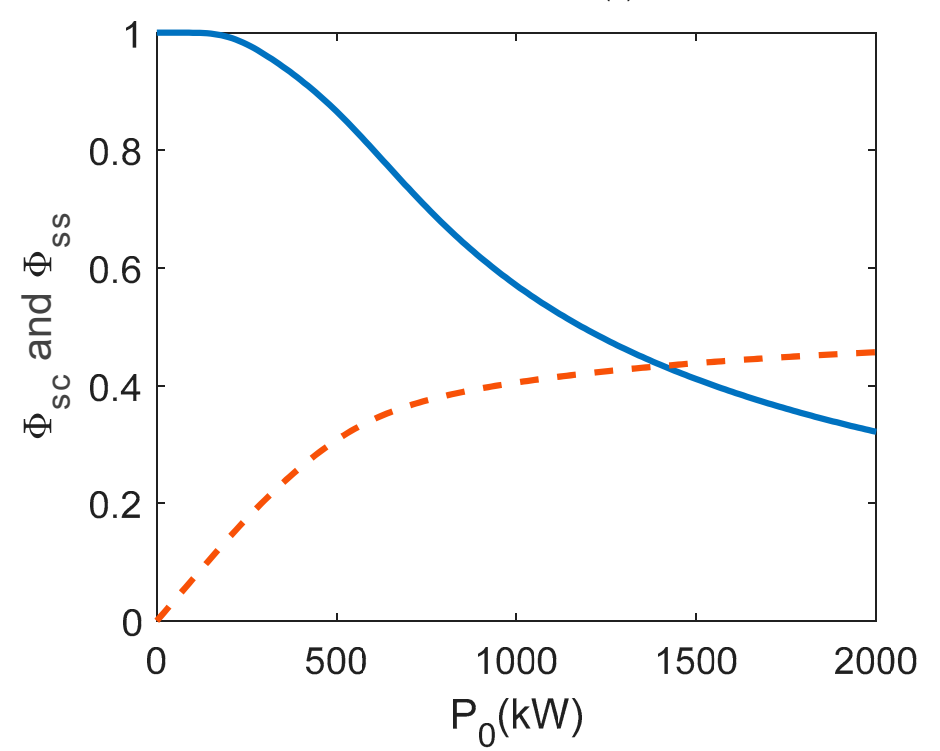

(b)
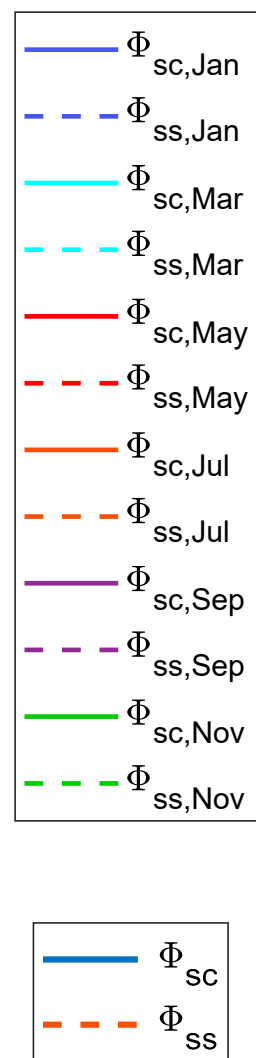

Figure 7. (a) Monthly self-consumption and self-sufficiency curves; (b) Annual self-consumption and self-sufficiency curves. Industry A.

If a period of analysis of one year is considered, the annual self-sufficiency and self-consumption curves are obtained $(\tau=$ year), Figure $7 \mathrm{~b}$. As already indicated, a high level of use of the photovoltaic generated energy with a self-consumption index of 90 and $80 \%$ for generator powers of 400 and $600 \mathrm{kWp}$, respectively, stands out. Likewise, the self-sufficiency index shows a linear behavior up to a considerable array power: $400 \mathrm{kWp}$, where a self-sufficiency index slightly higher than $25 \%$ is achieved. From that point on, the self-sufficiency index increases as the generator power does, but this increase is no longer lineal. In fact, the slope of the curve decreases as the power increases. At the end of the power range studied, the increase in the self-sufficiency index is very poor in relation to the increase in power. The intersection of the two curves indicates the ZEI (Zero Energy Industry) point as an analogy related with Zero Energy Building (ZEB) point which corresponds to the residential sector [38,39], and in this 
case, it is reached for $1400 \mathrm{~kW}$. This point is characterized by the fact that the two indices are equal. From Equations (2) and (3) it can be deduced that for ZEI point the annual energy consumed matches the annual photovoltaic generated energy, i.e., if it were possible to use all the photovoltaic energy (e.g., using storage systems and demand side management, DSM), the company's entire consumption could be covered.

$$
\mathrm{ZEI} \Rightarrow \mathrm{E}_{\mathrm{L}, \tau}=\mathrm{E}_{\mathrm{PV}, \mathrm{gen}, \tau}
$$

Considering the new index defined in Section 2.2, new self-sufficiency curves, both monthly and annual, are now obtained, Figure 8. It can be seen that these curves have a similar shape to those shown in Figure 7, except that they are less asymptotic while relatively large self-sufficiency values are obtained. This new index restricts the analysis to sunshine hours where the photovoltaic array is generating. This index is not intended to replace the self-sufficiency index defined in the literature but to complement it as it can provide important information on the operation of PV self-consumption systems specially in the industrial sector. For monthly reporting analysis, Figure 8a, the curves are already more profiled, and higher self-sufficiency values are obtained than in the previous analysis of total hours, between $40 \%$ and $56 \%$, for a self-consumption index up to $90 \%$. Finally, if we consider an annual reporting period, Figure $8 \mathrm{~b}$, it is obtained a curve where the self-sufficiency index shows a linear behavior up to $400 \mathrm{kWp}$, where the annual self-sufficiency index for sunshine hours is close to $50 \%$ : half the annual consumption in the daytime may be covered by photovoltaics. For the array power range considered it may be higher than $85 \%$. That is, considering daytime hours and an array power of $2 \mathrm{MW}$, the self-consumption system may practically cover the energy consumption associated with that period. Moreover, as can be seen, a new point can be defined: ZEI $\mathrm{SH}_{\mathrm{H}}$. Now at this point, the energy consumed during sunshine hours would be equal to the energy provided by the array. In this sense, if all the photovoltaic generated energy would be used, it would be possible to face all the consumption restricted to sunshine hours, Equation (12). On this occasion, the ZEI to $750 \mathrm{~kW}$.

$$
\mathrm{ZEI}_{\mathrm{SH}} \Rightarrow \mathrm{E}_{\mathrm{L}, \mathrm{SH}, \tau}=\mathrm{E}_{\mathrm{PV}, \text { gen }, \tau}
$$

Considering the different self-sufficiency and self-consumption curves shown in Figures 7 and 8 , it can be indicated that the photovoltaic self-consumption system of $52.8 \mathrm{~kW}$ currently installed in industry A could increase its peak power up to $180 \mathrm{kWp}$ while maintaining a self-consumption index of $100 \%$ (all the energy generated would be completely used) and self-sufficiency indices, total and for sunshine hours, of 14 and 30\%, may be achieved, respectively. The usefulness of these curves for dealing with an appropriate sizing of this type of installation should be highlighted.

Regarding industry B, monthly self-consumption and self-sufficiency curves are shown in Figure 9a. It can be observed that there is a self-consumption of $100 \%$ between $100 \mathrm{~kW}$ and $150 \mathrm{~kW}$ depending on the month of the year, with self-sufficiency indices between $5 \%$ and $15 \%$. Thus, in January, the total use of the energy generated is achieved for powers below $150 \mathrm{~kW}$. On the other hand, April only presents a $100 \%$ self-consumption value to array powers below $100 \mathrm{~kW}$. In relation to the monthly self-sufficiency curves, it should be noted that these ones show a linear tendency for a certain power interval. Outside this interval, the growth is no longer linear, becoming asymptotic as aforementioned. For July, a self-sufficiency index of $62 \%$ is reached for an array power of $2 \mathrm{MW}$, while if this same power is considered in the month of January this index is slightly higher than $23 \%$. 

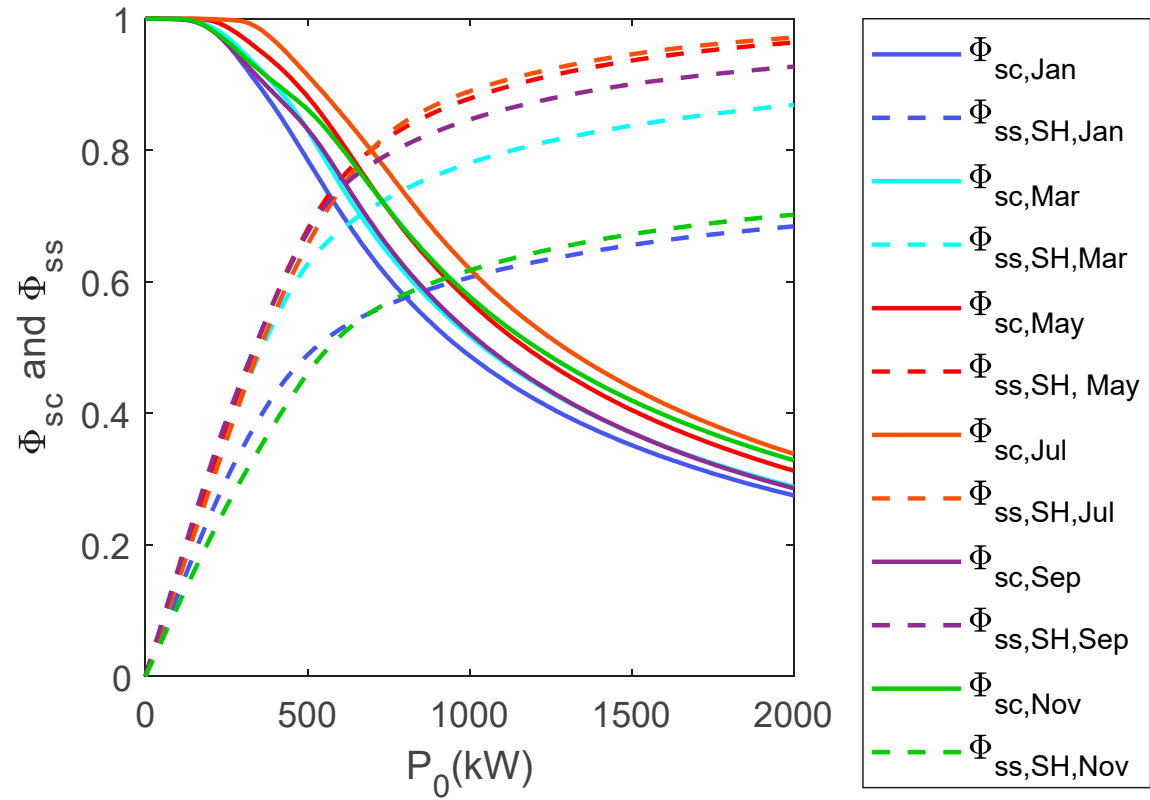

(a)
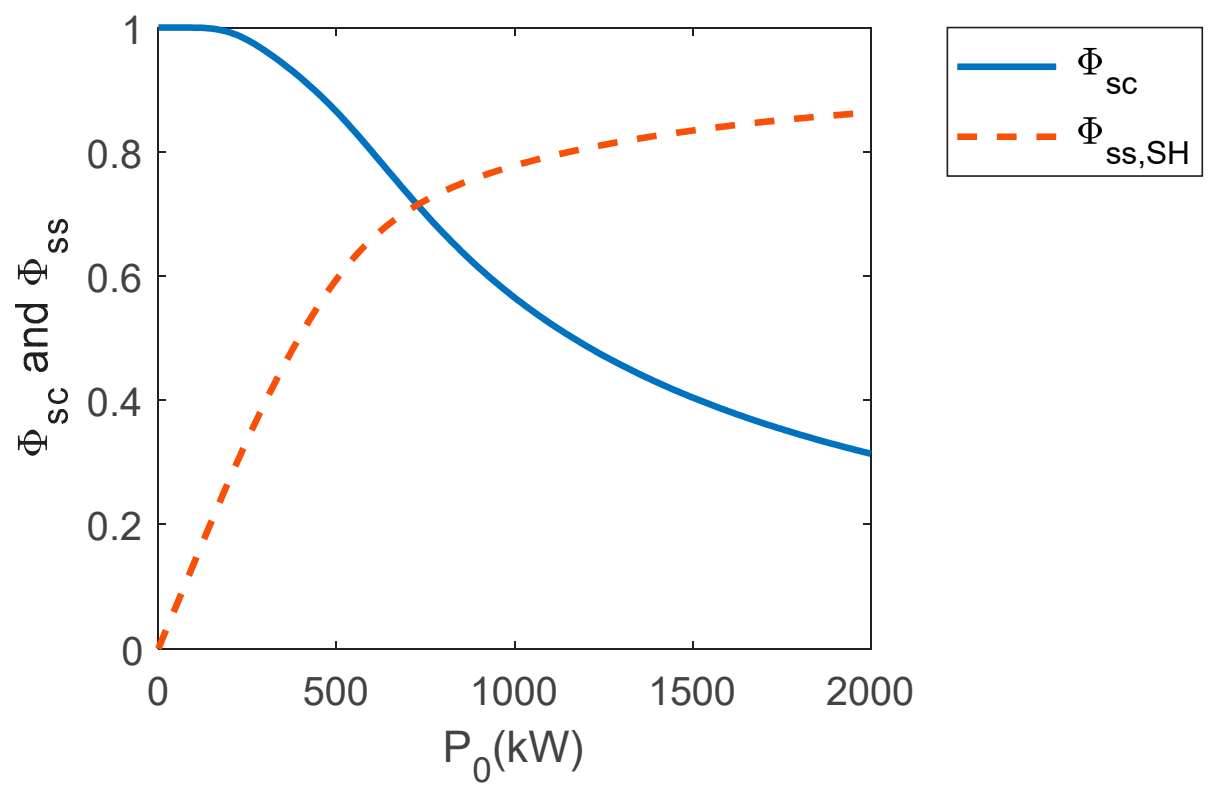

(b)

Figure 8. (a) Monthly self-consumption and self-sufficiency curves during sunshine hours; (b) Annual self-consumption and self-sufficiency curves during sunshine hours. Industry A

If an annual reporting period is considered, the annual self-consumption and self-sufficiency curves may be obtained, Figure $9 \mathrm{~b}$. As it occurred with industry A, a high level of use of the generated energy with a self-consumption index of 90 and $80 \%$ for array powers of 250 and $310 \mathrm{kWp}$, respectively, stands out. Likewise, the self-sufficiency index shows a linear behavior up to $200 \mathrm{kWp}$ where this index is close to $22 \%$. From that point on, the self-sufficiency index increases as the generator power does, but this increase is no longer proportional. At the end of the array power range considered, the increase in the self-sufficiency index is very poor in relation to the increase in power. Point ZEI, on this occasion, is placed at $900 \mathrm{kWp}$. 

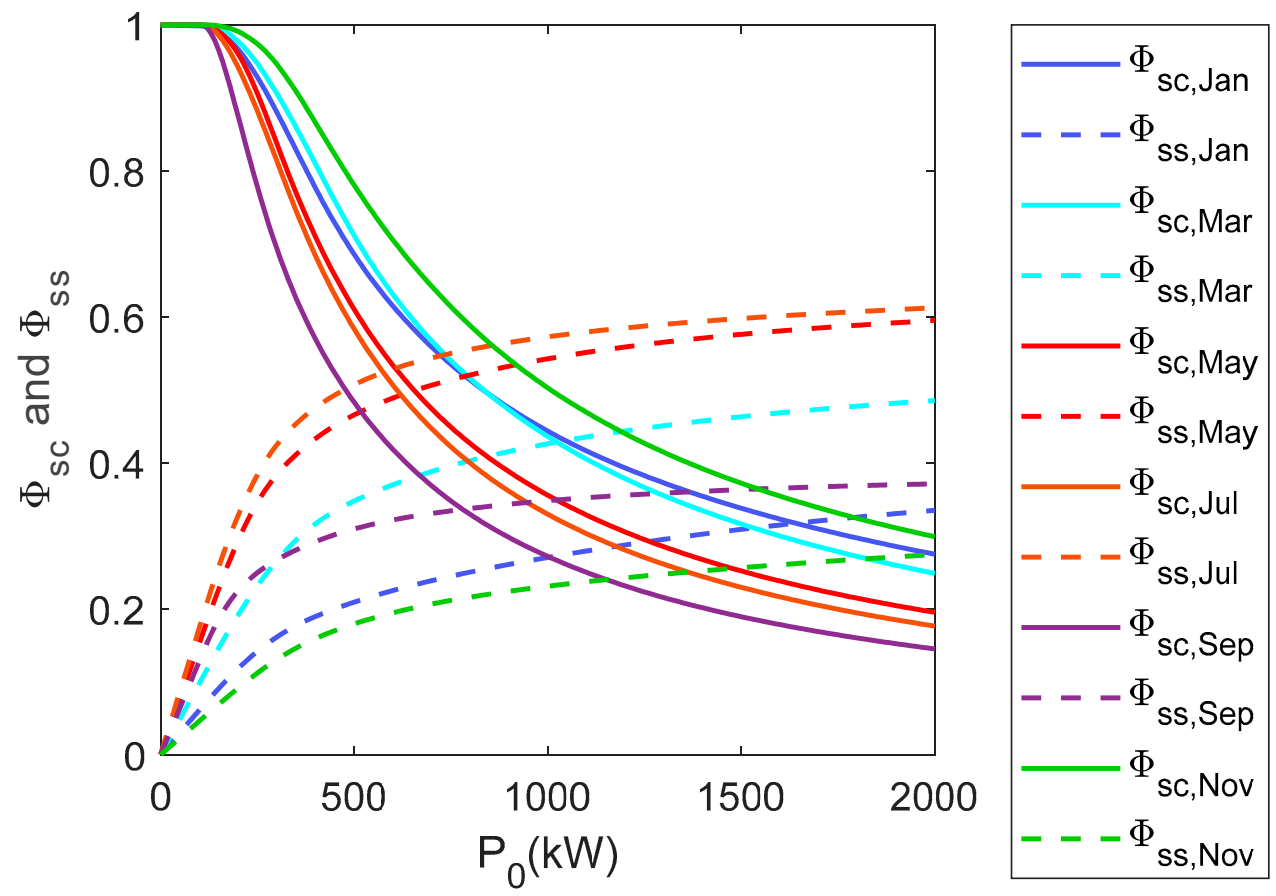

(a)

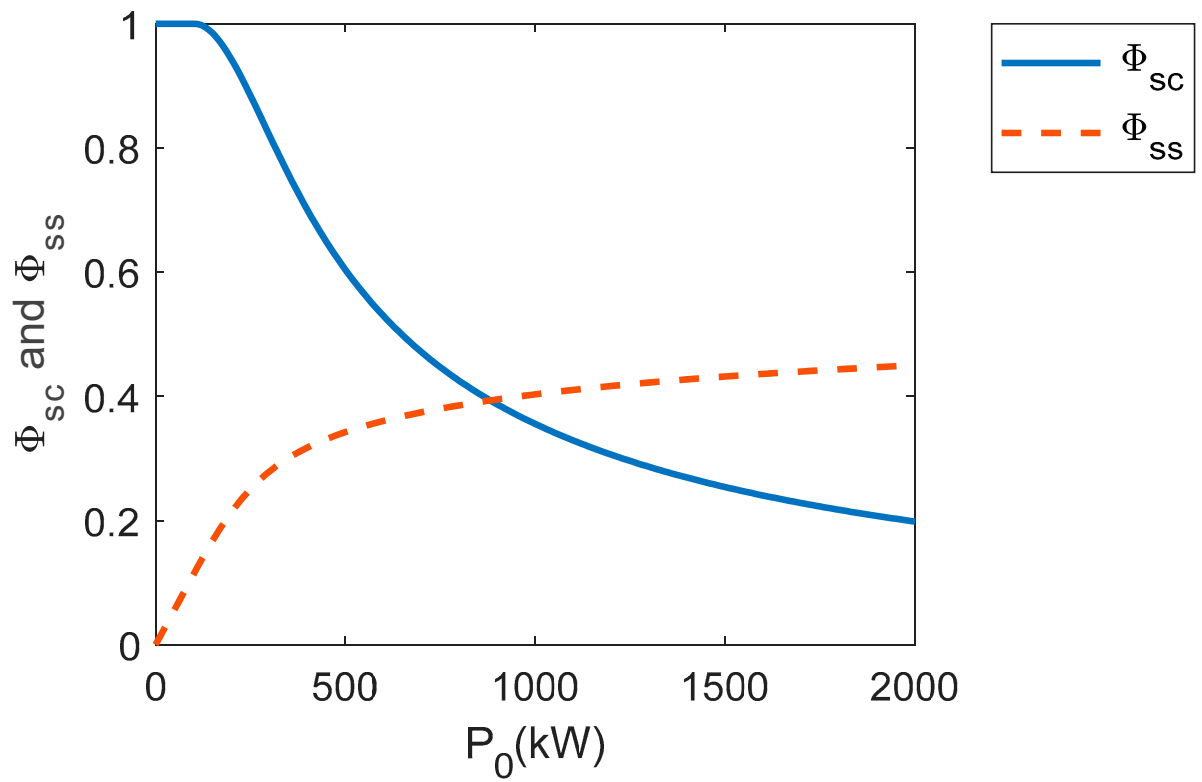

(b)

Figure 9. (a) Monthly self-consumption and self-sufficiency curves; (b) Annual self-consumption and self-sufficiency curves. Industry B.

If the analysis is focused on daytime, the self-sufficiency index for sunshine hours may be considered, Figure 10. As in industry A, the curves obtained in this case are different from the ones shown in Figure 9a. For $\tau=$ month, Figure 10a, higher self-sufficiency values than those estimated in the previous analysis of total hours are obtained, between 30\% (January) and 64\%, (September) for a $90 \%$ self-consumption index. Finally, if an annual reporting period is taken into account, Figure 10b a self-consumption index of $90 \%$ may be obtained for a photovoltaic generator power of $300 \mathrm{~kW}$, providing a self-sufficiency index for sunshine hours slightly higher than $45 \%$. In this case, $Z_{\text {ZEI }}$ point brings down to $450 \mathrm{~kW}$. 


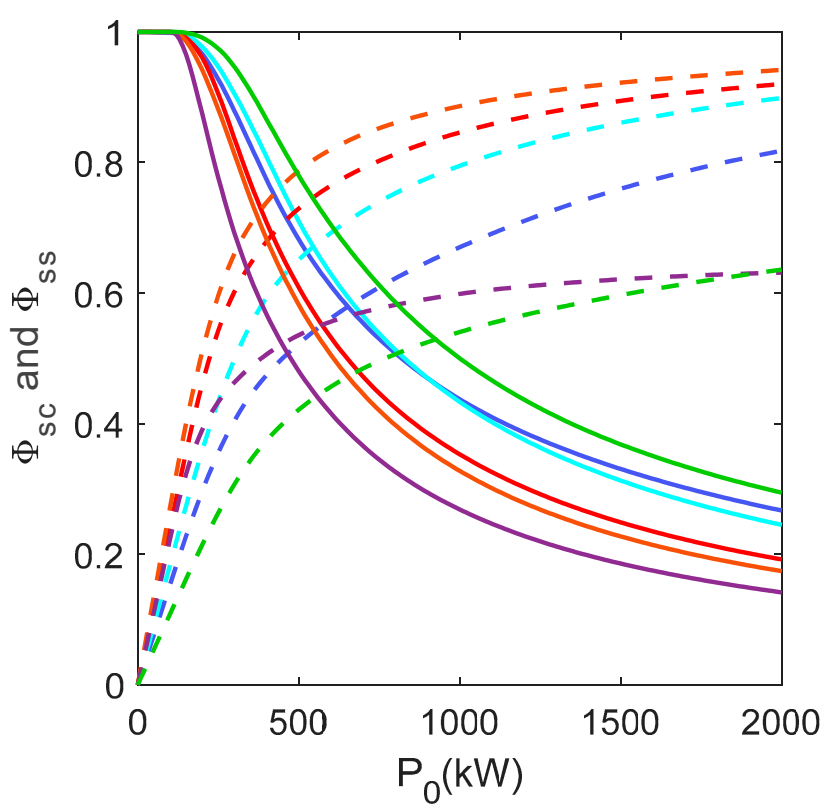

(a)

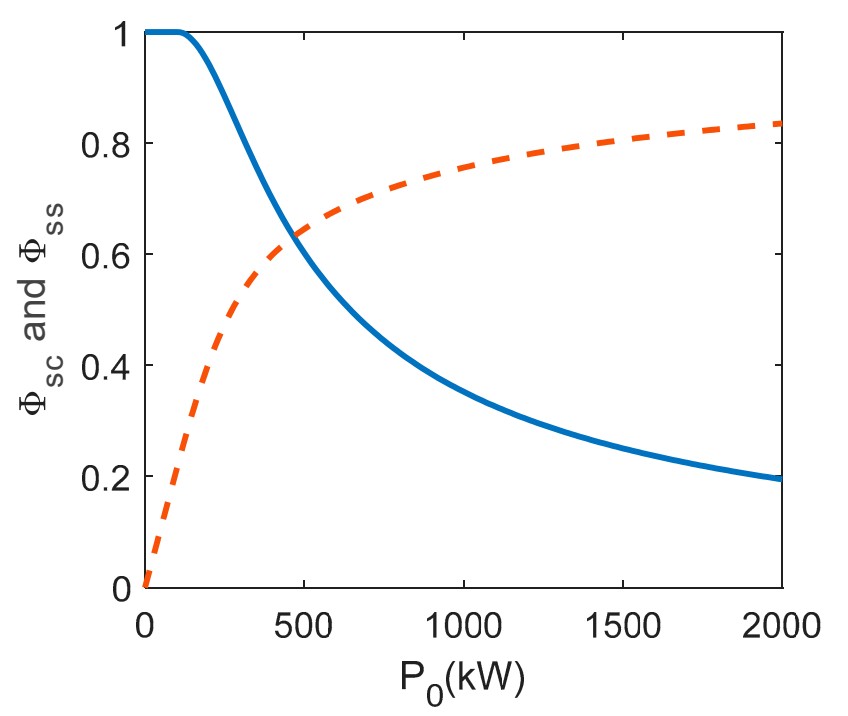

(b)
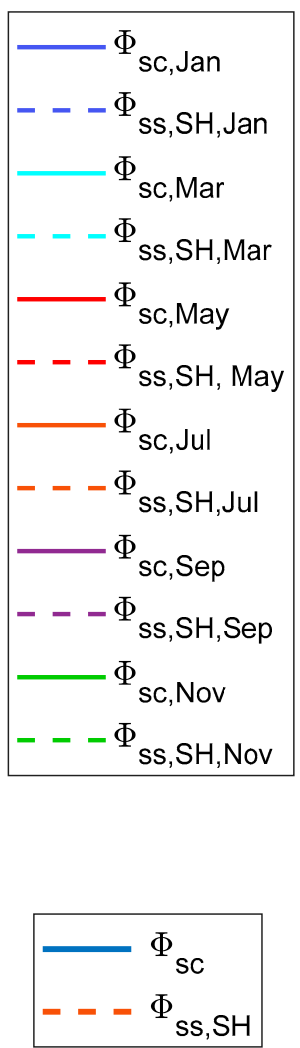

Figure 10. (a) Monthly self-consumption and self-sufficiency during curves sunshine hours; (b) Annual self-consumption and self-sufficiency curves during sunshine hours. Industry B.

These self-sufficiency and self-consumption curves, for both, total for sunshine hours, indicate that photovoltaic self-consumption may be a good choice for this type of industry characterized by a high basal and low variability consumption during daytime where a complete use of the photovoltaic energy generated may be achieved. Moreover, theses curves show that the photovoltaic installation of $110.2 \mathrm{kWp}$ currently installed in industry B is properly sized in order to cover a considerable portion of the consumption due to industrial cooling, maintaining a self-consumption rate of $100 \%$ and a self-sufficiency index for sunshine hours around $20 \%$.

To conclude the discussion and the analysis of the results, the self-consumption and self-sufficiency curves, curves for both total hours and sunshine hours are shown in Figure 11. The use of these self-sufficiency curves may be an interesting indicator when sizing the array in photovoltaic self-consumption systems in the industrial sector. 

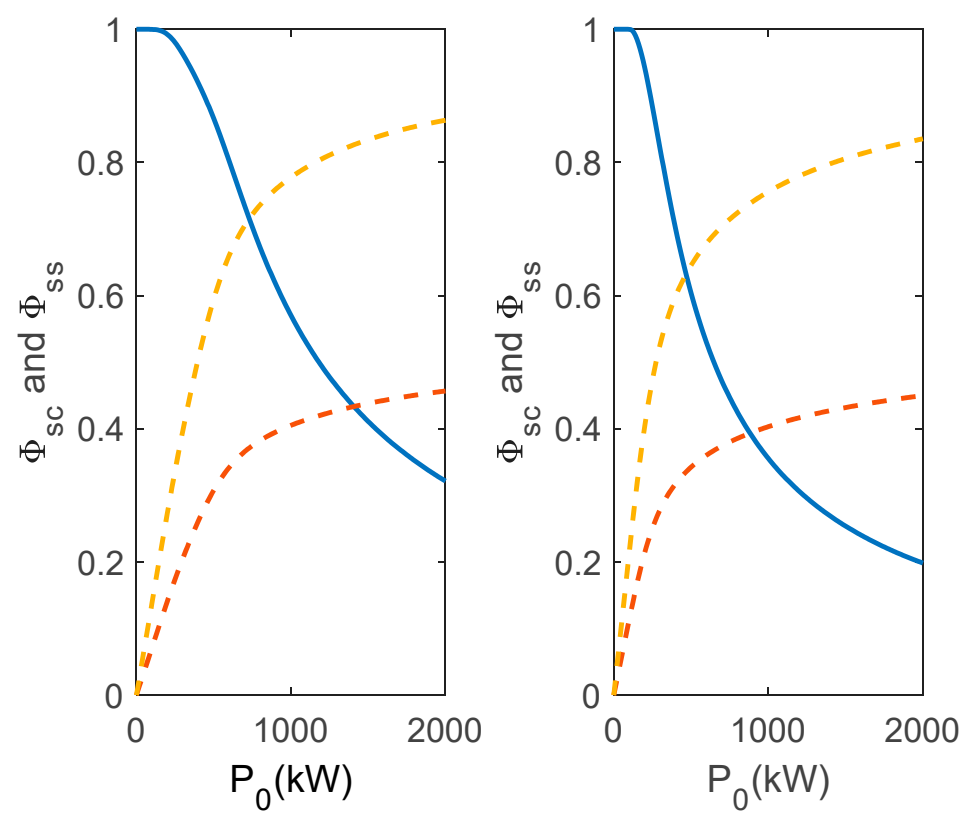

(a)

$$
\Phi_{\mathrm{SC}}=--\Phi_{\mathrm{SS}}-=-\Phi_{\mathrm{SS}, \mathrm{SH}}
$$

Figure 11. Annual self-consumption and self-sufficiency curves calculated with total hours (24h) and sunshine hours. (a) Industry A; (b) Industry B.

\section{Conclusions}

The suitability of photovoltaic self-consumption systems depends on the matching between photovoltaic generation and consumption profiles. In the industrial sector, unlike the residential one, it may be found too much different consumption profiles. In this sense, it is necessary to study the suitability of this technology to each type of industry considering its own consumption profile. Moreover, it may be necessary to define new indices and parameters which take into account the idiosyncrasy of this sector and, therefore, estimate better the performance of photovoltaic self-consumption systems in this sector.

In this manuscript it has been analyzed two photovoltaic self-consumption systems installed in two industries corresponding to the industrial refrigeration and cooling sector which have been monitored during a year. The nominal array power for industries A and B are 52 and $110 \mathrm{kWp}$, respectively. It has been shown how this type of industry presents a consumption profile with high basal and little variability consumption during daylight hours, and it may be an interesting candidate for photovoltaic self-consumption. Moreover, they suffer a considerable increase in consumption in summer that can be compensated for by the increase in electricity generation by the photovoltaic arrays in this same season. The self-consumption and self-sufficiency curves, considering a certain range of the photovoltaic generator power, have been used to analyze the suitability of photovoltaic self-consumption systems in this type of industry. In order to improve the matching analysis between the generation and consumption profiles of this type of systems, a new index, self-sufficiency index for sunshine hours, has been defined. This index, which complement the information provided by self-sufficiency index, evaluates the performance of the photovoltaic self-consumption system when facing the consumption only during sunshine hours. It indicates the level of coverage of this technology, limiting itself exclusively to the consumption existing in the period of time in which this energy source is active. At the same time, it makes it possible to better characterize photovoltaic self-consumption systems in the industrial sector where the consumption profile is very varied and can be unequally distributed throughout the day. It can be also interesting when different complementary energy sources to the electricity grid may be considered (e.g., wind and photovoltaic energy). 
For industry A and considering an annual reporting period, a high level of use of the energy generated may be achieved with a self-consumption index of $90 \%$ for array powers up to $400 \mathrm{kWp}$. Likewise, the self-sufficiency index shows an almost linear behavior up to this power, where a self-sufficiency index close to $25 \%$ is reached. Moreover, the annual self-sufficiency index for sunshine hours reaches almost $50 \%$. Regarding industry B, a $90 \%$ self-consumption index may be reached for an array power range up to $300 \mathrm{kWp}$. For this array power, self-sufficiency and a self-sufficiency for sunshine hours indices of 26 and $45 \%$, respectively, may be obtained. In this sense, the suitability of photovoltaic self-consumption systems for industrial cooling and refrigeration has been shown. Consumption and generation profiles corresponding to both industries provide a very high level of coupling for a relative high array power interval, up to $300 \mathrm{kWp}$, as self-consumption indices may be higher than $90 \%$. Moreover, taking into account the new index defined, both industries may cover half the annual consumption during daytime by photovoltaics considering the aforementioned array powers. These values highlight the suitability of photovoltaic self-consumption systems to this type of industry to photovoltaic self-consumption systems.

Furthermore, the new parameter defined here together with economic ones may be also used to provide a new design approach to better size the array in this type of systems. Further research should be done in this way.

Author Contributions: All authors contributed significantly to this study. Conceptualization, Methodology, Writing-original draft, Investigation: A.J.M.-C., F.J.M.-R., G.J.-C., P.G.-V., C.R.-C.; Data Curation: A.J.M.-C., G.J.-C., Supervision and technical review: A.J.M.-C., F.J.M.-R. All authors have read and agreed to the published version of the manuscript.

Funding: This research received no external funding.

Acknowledgments: The authors would like to thank the University of Jaén for its support in carrying out this research. It belongs to the the programme: "Acción 2 «Segunda Fase» comprendida en la "Línea de Actuación: Fomento y divulgación de la transferencia", enmarcada en el Objetivo 1: "Apoyo a las actividades de trasferencia del conocimiento", del Plan de Apoyo a la Transferencia del Conocimiento, el Emprendimiento y la Empleabilidad año 2017, para la contratación de doctorandos industriales"

Conflicts of Interest: The authors declare no conflict of interest.

\section{Abbreviations}

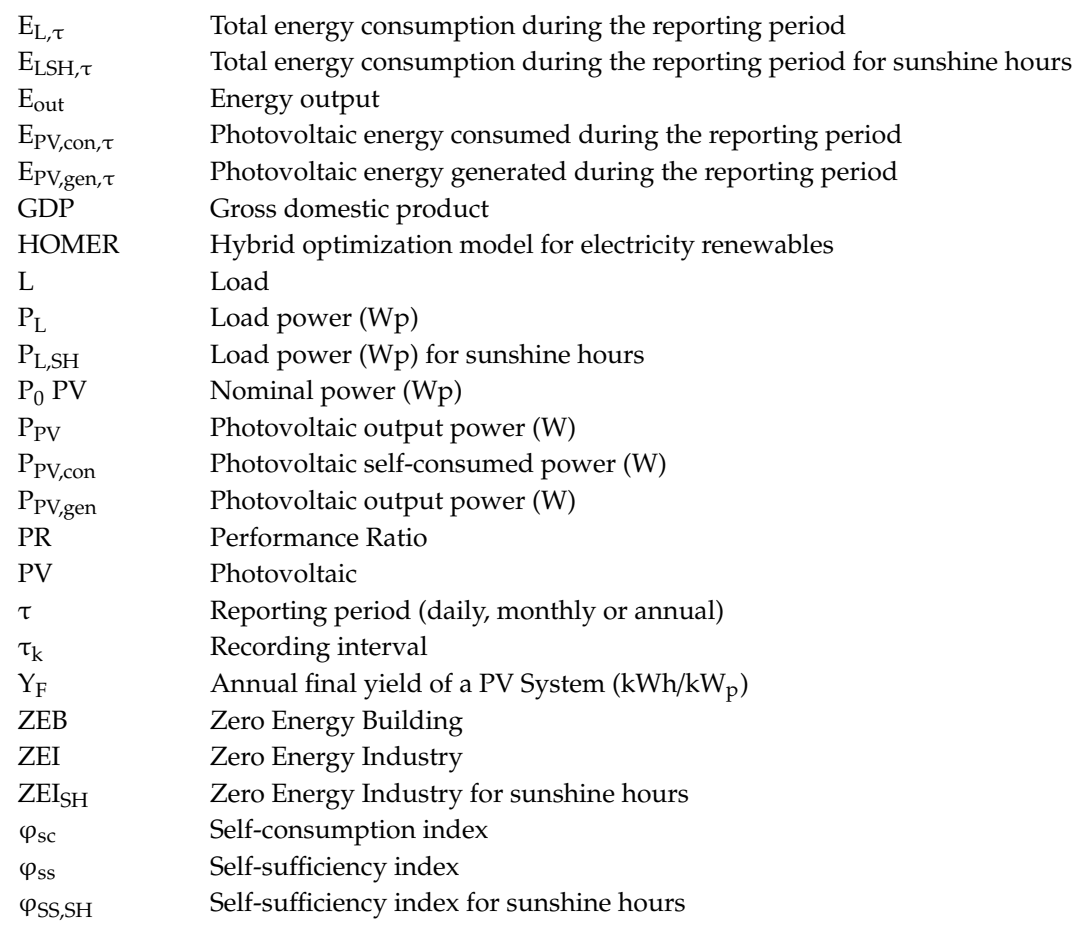




\section{References}

1. BP Statistical Review of World Energy. 2019. Available online: https://www.bp.com/content/dam/bp/business -sites/en/global/corporate/pdfs/energy-economics/statistical-review/bp-stats-review-2019-full-report.pdf (accessed on 20 October 2020).

2. IEA. Global Energy Review 2020; IEA Publication: Paris, France, 2020.

3. IDAE Institute for the Diversification and Saving of Energy. Available online: http://informeestadistico.idae. es/t10.htm (accessed on 8 September 2020).

4. Chiaroni, D.; Chiesa, V.; Colasanti, L.; Cucchiella, F.; D'Adamo, I.; Frattini, F. Evaluating solar energy profitability: A focus on the role of self-consumption. Energy Convers. Manag. 2014, 88, 317-331. [CrossRef]

5. Ehsan, A.; Yang, Q. Optimal integration and planning of renewable distributed generation in the power distribution networks: A review of analytical techniques. Appl. Energy 2018, 210, 44-59. [CrossRef]

6. Anuario Fotovoltaico. 2018. Available online: https://proyectotransicionenergetica.org/AnuarioFotovoltaico 2018.pdf (accessed on 20 October 2020).

7. Sarasa-Maestro, C.J.; Dufo-López, R.; Bernal-Agustín, J.L. Analysis of Photovoltaic Self-Consumption Systems. Energies 2016, 9, 681. [CrossRef]

8. European Parliament Directive 2009/2/EC of the European Parliament and of the Council of 13 July 2009. Available online: https://eur-lex.europa.eu/eli/dir/2009/72/oj (accessed on 20 December 2020).

9. Jenkins, N.; Strbac, J.; Ekanayake, G. Distributed Generation; Renewable Energy Series; IET: London, UK, 2010; ISBN 9780863419584.

10. Pelegry, Á.; Legarza, C. Generación Distribuida y Autoconsumo Análisis Regulatorio; Cátedra de Energía de Orkestra: Deusto, Spain, 2014.

11. González-Longatt, F.; Unefa, M.U.C.D.V.; Fortoul, C. Review of the Distributed Generation Concept: Attempt of Unification. Renew. Energy Power Qual. J. 2005, 1, 281-284. [CrossRef]

12. Luthander, R.; Nilsson, A.M.; Widén, J.; Åberg, M. Graphical analysis of photovoltaic generation and load matching in buildings: A novel way of studying self-consumption and self-sufficiency. Appl. Energy 2019, 250, 748-759. [CrossRef]

13. Lang, T.; Ammann, D.; Girod, B. Profitability in absence of subsidies: A techno-economic analysis of rooftop photovoltaic self-consumption in residential and commercial buildings. Renew. Energy 2016, 87, 77-87. [CrossRef]

14. Paciello, L.; Pedale, A.; Scaradozzi, D.; Conte, G. A design tool for modelling and sizing of energy production/storage home system. In Proceedings of the 2014 IEEE Workshop on Environmental, Energy, and Structural Monitoring Systems Proceedings, Naples, Italy, 17-18 September 2014; pp. 1-6.

15. Ghiani, E.; Vertuccio, C.; Pilo, F. Optimal sizing and management of a smart Microgrid for prevailing self-consumption. In Proceedings of the 2015 IEEE Eindhoven PowerTech, Eindhoven, The Netherlands, 29 June-2 July 2015; pp. 1-6.

16. Clairand, J.-M.; Briceno-Leon, M.; Escriva-Escriva, G.; Pantaleo, A.M. Review of energy efficiency technologies in the food industry: Trends, barriers, and opportunities. IEEE Access 2020, 8, 48015-48029. [CrossRef]

17. Bernardi, E.; Bordons, C.; Mendes, P.R.; Normey-Rico, J.E.; Adam, E.J. Fault-tolerant energy management for an industrial microgrid: A compact optimization method. Int. J. Electr. Power Energy Syst. 2021, 124, 106342. [CrossRef]

18. Nacer, T.; Hamidat, A.; Nadjemi, O. A comprehensive method to assess the feasibility of renewable energy on Algerian dairy farms. J. Clean. Prod. 2016, 112, 3631-3642. [CrossRef]

19. Javid, Z.; Li, K.-J.; Hassan, R.U.; Chen, J. Hybrid-microgrid planning, sizing and optimization for an industrial demand in Pakistan. Teh. Vjesn. Tech. Gaz. 2020, 27, 781-792. [CrossRef]

20. Jara, P.G.B.; Castro, M.T.; Esparcia, J.E.A.; Ocon, J.D. Quantifying the techno-economic potential of grid-tied rooftop solar photovoltaics in the Philippine industrial sector. Energies 2020, 13, 5070. [CrossRef]

21. Mukisa, N.; Zamora, R.; Lie, T.T. Feasibility assessment of grid-tied rooftop solar photovoltaic systems for industrial sector application in Uganda. Sustain. Energy Technol. Assess. 2019, 32, 83-91. [CrossRef]

22. Vokas, G.; Klironomos, P.; Kaldellis, J. Evaluation of building integrated photovoltaic systems' potential in the industrial sector: Case study of Oinofyta-Viotia zone, Greece. J. Energy Power Eng. 2013, 7, 2211-2219.

23. E Silva, L.G.L.; Dias, W.P.; Vieira, C.B.; Assis, P.S. Solar photovoltaic energy applied to ferroalloy industry. REM-Int. Eng. J. 2019, 72, 251-255. [CrossRef] 
24. Saxena, S.; Gaur, M.K.; Sinha, D.; Malvi, C.S.; Mishra, S.; Professor, A. Design of photovoltaic system for a biscuit packing machine. Int. J. Eng. Sci. Emerg. Technol. 2013, 6, 2231-6604.

25. Gómez-Lorente, D.; Rabaza, O.; Dols, F.A.; Mercado-Vargas, M.J. Economic and environmental study of wineries powered by grid-connected photovoltaic systems in Spain. Energies 2017, 10, 222. [CrossRef]

26. Rabaza, O.; Contreras-Montes, J.; García-Ruiz, M.J.; Hervás-Gámez, C.; Gómez-Lorente, D. Techno-economic performance evaluation for olive mills powered by grid-connected photovoltaic systems. Energies 2015, 8, 11939-11954. [CrossRef]

27. Jiménez-Castillo, G.; Muñoz-Rodríguez, F.; Martinez-Calahorro, A.J.; Tina, G.M.; Rus-Casas, C. Impacts of array orientation and tilt angles for photovoltaic self-sufficiency and self-consumption indices in olive mills in Spain. Electronics 2020, 9, 348. [CrossRef]

28. International Institute of Refrigeration. 29th Informatory Note on Refrigeration Technologies: The Role of Refrigeration in the Global Economy; IIF-IIR: Paris, France, 2015.

29. Jiménez-Castillo, G.; Rus-Casas, C.; Tina, G.M.; Muñoz-Rodriguez, F. Effects of smart meter time resolution when analyzing photovoltaic self-consumption system on a daily and annual basis. Renew. Energy 2020, 164, 889-896. [CrossRef]

30. Hernandez, J.C.; Ruiz-Rodriguez, F.; Jurado, F. Modelling and assessment of the combined technical impact of electric vehicles and photovoltaic generation in radial distribution systems. Energy 2017, 141, 316-332. [CrossRef]

31. Gomez-Gonzalez, M.; Hernandez, J.C.; Vera, D.; Jurado, F. Optimal sizing and power schedule in PV household-prosumers for improving PV self-consumption and providing frequency containment reserve. Energy 2020, 191, 116554. [CrossRef]

32. Jiménez-Castillo, G.; Muñoz-Rodríguez, F.; Rus-Casas, C.; Talavera, D. A new approach based on economic profitability to sizing the photovoltaic generator in self-consumption systems without storage. Renew. Energy 2020, 148, 1017-1033. [CrossRef]

33. IEC. Photovoltaic System Performance-Part. 1: Monitoring, 1st ed.; IEC Publications: Geneva, Switzerland, 2017; ISBN 9782832239889.

34. Talavera, D.; Muñoz-Rodríguez, F.; Jimenez-Castillo, G.; Rus-Casas, C. A new approach to sizing the photovoltaic generator in self-consumption systems based on cost-competitiveness, maximizing direct self-consumption. Renew. Energy 2019, 130, 1021-1035. [CrossRef]

35. Luthander, R.; Widén, J.; Nilsson, D.; Palm, J. Photovoltaic self-consumption in buildings: A review. Appl. Energy 2015, 142, 80-94. [CrossRef]

36. Iqbal, M. An Introduction to Solar Radiation; Elsevier: Amsterdam, The Netherlands, 1983.

37. Wolisz, H.; Schütz, T.; Blanke, T.; Hagenkamp, M.; Kohrn, M.; Wesseling, M.; Mueller, D. Cost optimal sizing of smart buildings' energy system components considering changing end-consumer electricity markets. Energy 2017, 137, 715-728. [CrossRef]

38. Vieira, F.M.; Moura, P.S.; De Almeida, A.T. Energy storage system for self-consumption of photovoltaic energy in residential zero energy buildings. Renew. Energy 2017, 103, 308-320. [CrossRef]

39. Torcellini, P.A.; Crawley, D.B. Understanding zero-energy buildings. Ashrae J. 2006, 48, 62-69.

Publisher's Note: MDPI stays neutral with regard to jurisdictional claims in published maps and institutional affiliations.

(C) 2020 by the authors. Licensee MDPI, Basel, Switzerland. This article is an open access article distributed under the terms and conditions of the Creative Commons Attribution (CC BY) license (http://creativecommons.org/licenses/by/4.0/). 